\title{
Assessing the Predictability of Existing Water-to- enamel Geolocation Models Against Known Human Teeth: Do We Need Tissue-Specific $\delta 180$ Reference Maps?
}

\author{
Momoko Ueda ( $\nabla$ mueda@sfu.ca ) \\ Simon Fraser University \\ Lynne S. Bell \\ Simon Fraser University
}

\section{Research Article}

Keywords: predictability, geolocation, isotope analysis, oxygen

Posted Date: March 17th, 2021

DOl: https://doi.org/10.21203/rs.3.rs-294531/v1

License: (c) (1) This work is licensed under a Creative Commons Attribution 4.0 International License. Read Full License

Version of Record: A version of this preprint was published at Scientific Reports on August 2nd, 2021. See the published version at https://doi.org/10.1038/s41598-021-95153-w. 
1 Title: Assessing the predictability of existing water-to-enamel geolocation

2 models against known human teeth: Do we need tissue-specific $\square{ }^{18} \mathrm{O}$

3 reference maps?

$4 \quad$ Momoko Ueda ${ }^{1 *}$, Lynne S. Bell ${ }^{1 *}$

$5{ }^{1}$ School of Criminology, Centre for Forensic Research, Simon Fraser University, Burnaby, British

6 Columbia, Canada

$7 *$ Corresponding authors

8 E-mail: mueda@sfu.ca (MU); 1ynneb@sfu.ca (LSB)

\section{Abstract}

10 Stable isotope analysis of human tissues has become a valuable tool for mapping human

11 geolocation. This study adds to the existing knowledge of the relationship between oxygen stable

12 isotopes in human enamel ( $\left.\square{ }^{18} \mathrm{O}_{\text {enam }}\right)$ and drinking water $\left(\square^{18} \mathrm{O}_{\mathrm{dw}}\right)$ by presenting $\square{ }^{18} \mathrm{O}_{\text {enam }}$

13 values in clinic-extracted human dental enamel with known provenance. The results from this

14 study indicate that the theoretical isotopic relationship between ${ }^{18} \mathrm{O}_{\mathrm{enam}}$ and ${ }^{18} \mathrm{O}_{\mathrm{dw}}$ is valid

15 although weak at the city and country-level. However, differences of up to $15 \%$ were observed

16 between predicted $\square{ }^{18} \mathrm{O}_{\mathrm{dw}}$ values using existing models and observed values, highlighting the

17 complexity of using enamel-to-water conversion equations. A city-specific range of $\square{ }^{18} \mathrm{O}_{\text {enam }}$

18 values is now understood for Metro Vancouver $\left[\square{ }^{18} \mathrm{O}_{\text {carbonate }}=-9.7 \%\right.$ to $-7.2 \%$ o $]$ and presents

19 the possibility of both including within the city of Vancouver and excluding individuals, utilizing

Updated: March 17, 2021 
20 stable oxygen analysis as an exclusionary tool. Overall, this study's results support the

21 development of tissue-specific ${ }^{18} \mathrm{O}_{\text {enam }}$ geographical reference maps for human geolocation.

22

Updated: March 17, 2021 


\section{Introduction}

24 Human tooth enamel stable oxygen isotope composition $\left(\square^{18} \mathrm{O}_{\text {enam }}\right)$ has been used to localize

25 region-of-origin of unknown human remains. ${ }^{18} \mathrm{O}_{\text {enam }}$ ratios predominantly reflect stable oxygen

26 isotope composition in drinking water $\left(\square{ }^{18} \mathrm{O}_{\mathrm{dw}}\right)$ influenced by local precipitation water, which

27 varies globally and can provide information on an individual's geographical history ${ }^{1,2}$. Such data

28 can help forensic investigations narrow down missing person searches by complementing other

29 conventional identification methods such as fingerprint or DNA analysis. The current approach

30 to human provenancing utilizes predictive models to estimate $\square{ }^{18} \mathrm{O}_{\mathrm{dw}}$ values from $\square{ }^{18} \mathrm{O}_{\text {enam }}$

31 values. Individuals are subsequently placed on a geographical map, otherwise known as

32 isoscapes.

34 Isoscapes for stable oxygen have been developed for precipitation and tap water, mainly at the

35 country level ${ }^{1,3}$, but also for more constrained geographical areas such as the state of Mississippi,

36 U.S. ${ }^{4}$. There has also been an attempt to create an isoscape for $\square{ }^{18} \mathrm{Oenam}_{\text {values }}$. However, it is

37 vital to recognize that isoscapes do not represent actual data spread but are instead extrapolated

38 models, often based on limited measurements ${ }^{6}$. A suggested alternative empirical approach to

39 human geolocation involves the direct mapping of the tissue isotopes themselves, thus

40 eliminating any errors associated with the use of regression models ${ }^{7-9}$. However, mathematical

41 models are important for predicting human origin in areas where either human or drinking water

42 data do not exist. What is key to creating a reliable model for assisting with missing persons

43 cases is to ensure that the baseline data and hence, $\square{ }^{18} \mathrm{O}_{\mathrm{dw}}$ to $\square{ }^{18} \mathrm{O}_{\text {enam }}$ equations, accurately

44 represent true relationships. Further, the predictability of such equations remains uncertain. Updated: March 17, 2021 
46 Enamel is extremely resistant to post mortem alteration due to its high mineral composition

$47(95 \%)$ in the form of calcium carbonate or phosphate hydroxyapatite $\left(\mathrm{Ca}_{10}\left(\mathrm{PO}_{4}, \mathrm{CO}_{3}\right)_{6}(\mathrm{OH})_{2}\right)^{10,11}$.

48 The stable oxygen isotope compositions in enamel hydroxyapatite can be determined by

49 analyzing the more abundant phosphate or the structural carbonate substitute ${ }^{12} \cdot \square^{18} \mathrm{O}_{\text {enam values }}$

50 analyzed from both phosphate and structural carbonate are shown to have a direct positive

51 relationship with $\square{ }^{18} \mathrm{O}_{\text {ppt }}$ or $\square{ }^{18} \mathrm{O}_{\mathrm{dw}}$ values ${ }^{13-15}$. Phosphate analysis has generally been the

52 preferred analytical methodology for archaeological materials due to the high resistance to the

53 environmental exchange of oxygen ${ }^{16}$. Conversely, structural carbonate is more susceptible to

54 diagenetic alterations compared to phosphate but is more cost-effective and allows for robust

55 analysis in terms of the amount of material required ${ }^{17}$. The susceptibility to diagenetic alterations

56 is less of an issue with forensic samples due to the limited time in which enamel experiences

57 environmental exposure. The relationship between carbonate and phosphate oxygen has been

58 investigated for mammalian ${ }^{18,19}$ and human bioapatite ${ }^{20,21}$.

60 Oxygen from body water is incorporated into enamel bioapatite at a constant temperature of

$6137^{\circ} \mathrm{C}$ during tooth formation, preserving the isotopic record of body water oxygen within the

62 enamel tissue. Three primary forms of oxygen input that influence the isotopic compositions of

63 oxygen in body water $\left(\square{ }^{18} \mathrm{O}_{\mathrm{bw}}\right)$ are drinking water $\left(\square{ }^{18} \mathrm{O}_{\mathrm{dw}}\right)$, food water $\left(\square{ }^{18} \mathrm{O}_{\mathrm{fw}}\right)$, and

64 atmospheric oxygen $\left(\square^{18} \mathrm{O}_{\mathrm{atm}}\right)$. The main source of oxygen in body water has been shown to

65 come from drinking water ${ }^{22} . \square^{18} \mathrm{O}_{\mathrm{fw}}$ values also contribute to the overall $\square{ }^{18} \mathrm{O}_{\mathrm{bw}}$ values,

66 although believed to be small for humans, unlike herbivores whose isotopic signature of oxygen Updated: March 17, 2021 
67 in the hydroxyapatite may be influenced by the relatively larger proportion of oxygen due to

68 increased consumption of plants ${ }^{9,23}$. Further, the contribution of ${ }^{18} \mathrm{O}$ atm to ${ }^{18} \mathrm{Obw}$ is approximately

$6920 \%$ and globally homogeneous at an average $\square{ }^{18} \mathrm{Oatm}$ value of $+23 \%{ }^{14}$. Oxygen isotopic

70 compositions in human enamel are, therefore, strongly influenced by meteoric water.

72 The global geospatial isotopic pattern of meteoric water is dependent on local physiographic

73 factors such as latitude, altitude, and the distance from the coast (Dansgaard, 1964; Rozanski,

74 Araguás-Araguás, \& Gonfiantini, 1993), with stable oxygen isotope values decreasing with

75 increasing latitude (Bowen \& Wilkinson, 2002). Global precipitation data is readily available

76 through the Global Network of Isotopes in Precipitation, a monitoring network with collection

77 stations located worldwide (IAEA/WMO, 2020). The Online Isotopes in Precipitation Calculator

78 (OIPC) also provides a means to estimate $\square{ }^{18} \mathrm{O}_{\mathrm{ppt}}$ values for any geographical location from

79 latitudinal, longitudinal, and elevational data (Bowen, 2018). Local precipitation water feeds into

80 drinking water reservoirs, allowing $\square{ }^{18} \mathrm{O}_{\mathrm{ppt}}$ values to be good proxies for $\square{ }^{18} \mathrm{O}_{\mathrm{dw}}$ values.

82 While ${ }^{18} \mathrm{O}_{\text {ppt }}$ can influence ${ }^{18} \mathrm{O}_{\mathrm{dw}}$ ratios, the degree to which one translates to another in modern

83 society is dependent on several factors, such as the type of drinking water sources, climatic

84 characteristics, and water infrastructure ${ }^{24,25}$. There is a heightened reliance on complex water

85 distribution systems for safe drinking water delivery and is notably essential for high density and

86 expanding metropolitan regions ${ }^{26,27}$. Tap water distribution systems often draw water from

87 multiple water sources or geographically distant areas with varying physiography ${ }^{28}$ to meet

88 growing communities' demands. This ultimately leads to significant offsets in tap water oxygen Updated: March 17, 2021 
$89\left(\square{ }^{18} \mathrm{O}_{\text {tap }}\right.$ ) values compared to that of local $\square{ }^{18} \mathrm{O}_{\mathrm{ppt}}$ values. It is becoming crucial to understand

90 the source and distribution of drinking water to accurately determine the fractional contribution

91 of ${ }^{18} \mathrm{O}_{\mathrm{dw}}$ to ${ }^{18} \mathrm{O}$ enam, particularly with the modern population increasingly relying on piped water

92 systems. It is especially vital because of the heavy influence of ${ }^{18} \mathrm{O}_{\mathrm{dw}}$ on ${ }^{18} \mathrm{O}_{\mathrm{bw}}$ and subsequently

93 on ${ }^{18}$ Oenam ratios.

94

95 There is an increased understanding of the isotopic patterns of tap water across large

96 geographical areas such as the conterminous United States ${ }^{29,30}$, Mexico $^{31}$, South Africa ${ }^{32}$, and

$97 \mathrm{China}^{33}$, as well as for defined metropolitan areas where studies have shown that isotopic values

98 closely follow its distribution systems ${ }^{34,35}$. Ueda and Bell ${ }^{35}$ showed that $\square{ }^{18} \mathrm{O}_{\text {tap }}$ values of

99 Metro Vancouver (MV) uniquely follow the three primary water sources' distribution patterns-

100 Capilano, Seymour, and Coquitlam watersheds. The regional district includes 21 municipalities,

101 one electoral area, and one treaty of First Nations. Tap water is delivered to each municipality

102 through a modern water distribution system closely monitored and operated by the Metro

103 Vancouver Water Services ${ }^{36}$. This highly detailed understanding of the source and distribution of

104 tap waters across MV allows for a precise evaluation of the relationship between $\square{ }^{18} \mathrm{O}_{\text {enam }}$ and

$105 \square{ }^{18} \mathrm{O}_{\mathrm{dw}}$ values through the careful collection and the analysis of both modern tap water and

106 enamel samples with known geographical information.

107

108 This study aims to validate the theoretical understanding of the drinking water-to-enamel

109 relationship through a paired analysis of known modern $\square{ }^{18} \mathrm{O}_{\mathrm{c}}$ and $\square{ }^{18} \mathrm{O}_{\text {dw }}$ values focusing on a

110 single regional district of Metro Vancouver, British Columbia, Canada. Additionally, results Updated: March 17, 2021 
111 from this study will be compared against existing predictive models to determine how well they

112 perform against known modern samples.

113

\section{Methods}

\section{Ethics Permission}

116 This research project has been approved by the Associate Director, Simon Fraser University

117 Office of Research Ethics, on behalf of the Research Ethics Board under the study number

118 [2015s0125]. Informed consent was obtained from all subjects, and all experiments were

119 performed in accordance with University Policy R20.01

120 (http://www.sfu.ca/policies/gazette/research/r20-01.html).

\section{Collection and analysis of tooth samples}

123154 empty vials were sent out to dental clinics across Metro Vancouver during the years 2015 to

124 2017. 126 vials were returned with extracted human molar samples comprised of first, second,

125 and third molars. Molars were placed in $20 \mathrm{~mL}$ scintillation vials labelled with sample identifiers

126 following the extraction and returned to the laboratory for storage. Immense care was taken to

127 obtain information from individuals on residence location and any relocations from birth to 25

128 years to ensure that known geographical information was acquired directly from individuals for

129 the entire duration of tissue formation (Table 1). This information was vital for ensuring that $\square$

$130 \quad{ }^{18} \mathrm{O}_{\text {enam values were matched with appropriate }} \square{ }^{18} \mathrm{O}_{\text {tap }}$ values from the location of tissue

131 formation.

Updated: March 17, 2021 
133 Collected molars were cleansed with tap water and dried for at least 24 hours before drilling.

134 Core enamel was extracted into powdered form $(\sim 1 \mathrm{mg})$ by gentle abrasion with a diamond-

135 tipped hand-held drill (Dremel). The enamel's external surface was mechanically removed and

136 discarded prior to sampling of core enamel to ensure sampled areas were devoid of dental

137 calculus and overt caries. Care was taken to ensure no dentine was sampled, and the drill was

138 cleaned of any enamel powder with compressed air between each sample. Enamel powder was

139 prepared after Lee-Thorp et al. ${ }^{37}$. The powder was soaked in $50 \%$ sodium hypochlorite for 45 to

14060 minutes, centrifuged, and rinsed with distilled water. The powder was then reacted with 0.1

141 M acetic acid for 5 to 15 minutes, thoroughly rinsed with distilled water then freeze-dried.

143 Samples were weighed into $12 \mathrm{ml}$ borosilicate tubes (Labco, Ceredigion, U.K.) and closed with

144 screw top lids containing a septum. The tubes were placed in a sampler tray temperature-

145 controlled to $72{ }^{\circ} \mathrm{C}$. Using the CTC Analytics A200S autosampler (Switzerland) the tubes were

146 flushed with helium to remove any atmospheric air present within them. 5 to 7 drops (according

147 to sample size) of warm $\left(72{ }^{\circ} \mathrm{C}\right)$ acid (85\% orthophosphoric acid and phosphorus pentoxide,

148 specific gravity of solution $=1.92$ ) were then manually added to each sample tube through the

149 septum using a $1 \mathrm{ml}$ syringe. The samples were left to react for three hours before running the

150 analysis. The gas evolved from each reaction was sampled by the autosampler and passed to a

151 Thermo Finnigan (Germany) model II gasbench, where the sample gas was passed through a

152 Nafion water removal unit. It then passed through the "Poraplot Q" G.C. column to separate the

153 gas compounds released by the reaction, and then through a second Nafion water trap. The gas

Updated: March 17, 2021 
154 was then passed from the gasbench to a Delta Plus XP isotope ratio mass spectrometer (IRMS)

155 (Thermo electron, Bremen, Germany) computer-controlled by Isodat software. The gasflow was

156 controlled to give 8 sample peaks and 5 reference peaks. The $\mathrm{CO}_{2}$ reference gas $(99.995 \%$

157 purity) was introduced into the mass spectrometer via the gasbench, which was also controlled

158 by the Isodat software.

160 Oxygen analyses were carried out on the structural carbonate of tooth enamel. Isotopic results

161 are reported in conventional $\square$ - notation in units of per mil (\%) with reference to Vienna Pee

162 Dee Belemnite (VPDB) carbonate and calculated according to the equation:

$$
\delta^{18} O_{s t d}=\frac{R\left({ }^{18} O /{ }^{16} O\right)_{P}}{R\left({ }^{18} O /{ }^{16} O\right)_{s t d}}-1
$$

166 where $\mathrm{R}=$ ratio of the abundance of heavier ${ }^{18} \mathrm{O}$ to lighter ${ }^{16} \mathrm{O}$ isotopes in substance $\mathrm{P}$ and std $=$ 167 standards $^{38}$. Analytical precision was $\pm 0.2 \%$.

\section{Collection and analysis of annual $M V \delta^{18} \boldsymbol{O}_{\text {tap }}$ values}

170 Two treated tap water samples were collected monthly at both the Seymour-Capilano Filtration

171 Plant (SCFP) and the Coquitlam Water Treatment Plant (CWTP) from June 2017 to May 2018.

172 Samples were collected in air-tight 8-dram borosilicate glass vials and stored in a refrigerator to

173 prevent evaporation. 3 of the 48 collected tap water samples were discarded due to leakage

174 during transport, leaving only single measurements for June 2017 and May 2018 at CWTP and

Updated: March 17, 2021 
175 for October 2017 at SCFP, for a total of 45 tap water samples available for analysis. The water 176 samples were analyzed for oxygen through the Los Gatos Triple Liquid Water Isotope Analyzer

177 (TLWIA-45-EP 2013) connected to CTC Analytics LEAP Technology PAL liquid auto-sampler 178 and checked against Los Gatos Standards 1A, 2A, 3A, 4A and 5A. Instrumental precision was \pm $1790.1 \%$.

181 MV tap water is delivered to municipalities through interconnected water pipes originating from 182 the three main MV watersheds. Several municipalities additionally draw tap water from wells ${ }^{39}$. 183 Although the water distribution system is well monitored, the source of tap water delivered to the 184 municipalities through the interconnected water pipes can vary even by the hour. As a result, the 185 exact fractional contributions of end-member water sources to the overall municipal tap water 186 supply are unknown. The fractional contribution $(f)$ of each water source $(a, b, c, d)$ to the total 187 water supply can be expressed as:

$$
1=f_{(a)}+f_{(\mathrm{b})}+f_{(c)}+f_{(d)}
$$

189 Source information of tap water samples collected and reported in Ueda and Bell's ${ }^{35}$ study was 190 used to determine each water source's potential fractional contribution to MV municipality water 191 supply. The fractional contributions of each water source were then utilized to calculate the mean $192 \square{ }^{18} \mathrm{O}_{\text {tap }}$ values for each MV municipality:

$$
\delta{ }^{18} \mathrm{O}_{(\text {mean })}=\delta{ }^{18} \mathrm{O}_{(a)} * f_{(a)}+\delta{ }^{18} \mathrm{O}_{(b)} * f_{(b)}+\delta{ }^{18} \mathrm{O}_{(c)} * f_{(c)}+\delta{ }^{18} \mathrm{O}_{(d)} * f_{(d)}
$$

194 Drinking water from Capilano and Seymour watersheds was treated under two separate facilities 195 until the Seymour-Capilano Twin Tunnel construction in 2015, which now connects water from 
196 the Capilano watershed to the Seymour-Capilano Filtration Plan before distribution to the 197 municipalities $^{39}$.

199 Data collection of $\delta^{18} \boldsymbol{O}_{d w}$ values for individuals placed outside of MV

200 Isotopic data on $\delta{ }^{18} \mathrm{O}_{\mathrm{dw}}$ values for cities outside of MV were retrieved from existing publications

201 for comparisons with $\delta^{18} \mathrm{O}_{\mathrm{c}}$ values. The preferred drinking water type was tap water with known

202 source water information. Tap water data without any indications of the actual source of tap

203 water were also collected but with the understanding that it may represent mixed water sources if 204 supplied by multiple water sources. The temporal representation of the data, whether annual or a 205 one-time collection, was also noted. Isotopic data of actual or possible source water were taken 206 as an alternative when tap water data did not exist. Average values were calculated if more than

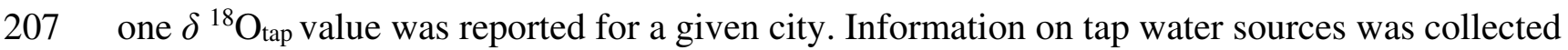
208 through municipal or governmental websites and from published studies. The OIPC ${ }^{40}$ and the 209 Regionalized Cluster-based Water Isotope Prediction (RCWIP) database ${ }^{41-43}$ were utilized to 210 estimate local $\square{ }^{18}$ OoIPC and $\square{ }^{18}$ ORCWIP values, respectively.

\section{Statistical analysis}

213 The pairwise t-test was used to test for differences between estimated $\delta^{18} \mathrm{O}_{\mathrm{ppt}}$ values retrieved

214 from the two databases at the $\alpha=0.05$ level. The ordinary least squares (OLS) method was

215 utilized to measure the correlation between $\delta^{18} \mathrm{O}_{\mathrm{c}}$ and $\delta^{18} \mathrm{O}_{\mathrm{dw}}$ values with adjusted r-squared $\left(\bar{R}^{2}\right)$

216 as the goodness-of-fit measure ${ }^{44}$. Coplen's ${ }^{45}$ equation was utilized for any conversions from

217 VPDB to Vienna Standard Mean Ocean Water (VSMOW). One-way analysis of variance Updated: March 17, 2021 
218 (ANOVA) tests were performed to compare means of $\delta^{18} \mathrm{O}_{\mathrm{c}}$ between cities, water sources, and 219 countries. When ANOVA assumptions were not met, the Kruskal-Wallis rank sum test ${ }^{46}$ was

220 performed as a non-parametric alternative to one-way ANOVA. Shapiro-Wilk' ${ }^{47}$ method was

221 used to test for normality of data. All mapping and statistical analyses were conducted on R

222 version $3.2 .3^{48}$

$224 \delta^{18} \boldsymbol{O}_{c}$ to $\delta^{18} \boldsymbol{O}_{d w}$ modelling and assessment of predictability

$225 \delta{ }^{18} \mathrm{O}_{\mathrm{c}(\mathrm{VSMOW})}$ values were converted to $\delta{ }^{18} \mathrm{O}_{\mathrm{dw}}$ values when predictive models allowed for direct 226 conversions. $\delta^{18} \mathrm{O}_{\mathrm{c}}$ to $\delta^{18} \mathrm{O}_{\mathrm{p}}$ conversion equations (Table 2) were utilized when conversions to $\delta$

$227{ }^{18} \mathrm{O}_{\mathrm{p}}$ values were necessary for comparison purposes. Predicted $\delta{ }^{18} \mathrm{O}_{\mathrm{dw}}$ values were regressed 228 against actual $\delta^{18} \mathrm{O}_{\text {tap }}$ values and $\delta{ }^{18} \mathrm{O}$ OIPC values separately to evaluate the performance of each

229 model or combination of models in cases where multiple conversions were needed. Predicted

230 values were deliberately placed on the $\mathrm{x}$-axis and observed values on the $\mathrm{y}$-axis to ensure correct

231 correlation estimates ${ }^{49}$. The regression analyses were complemented by the reporting of the mean 232 squared deviation (MSD) $)^{50,51}$ calculated as

$$
\mathrm{MSD}=\frac{1}{\mathrm{n}} \sum_{k=1}^{n}\left(x_{k}-y_{k}\right)^{2}
$$

234 which measures the degree of deviation from the equality line, where slope $=1$ and intercept $=0$.

235 MSD was preferred over the more commonly used statistic of mean squared error that measures

236 the mean deviation from the regression line rather than the equality line. MSD can further be

237 partitioned into three separate components and is the sum of squared bias (SB),

$$
\mathrm{SB}=(\bar{x}-\bar{y})^{2}
$$

239 non-unity slope (NU) where $b=\sum x_{n} y_{n} / \sum x_{n}^{2}$,

Updated: March 17, 2021 


$$
\mathrm{NU}=(1-b)^{2} *\left(\sum x_{n}^{2} * \frac{1}{n}\right)
$$

and lack of correlation (LC) where $r=\left(\sum x_{n} y_{n}\right)^{2} / \sum x_{n}^{2} \sum y_{n}^{2}$,

$$
\mathrm{LC}=\left(1-r^{2}\right) *\left(\sum y_{n}^{2} * \frac{1}{n}\right)
$$

243 The models or sets of models were then ranked according to MSD to determine the best

244 performing models for predicting $\delta^{18} \mathrm{O}_{\text {tap }}$ or $\delta{ }^{18}$ OoIPC values from observed $\delta{ }^{18} \mathrm{O}_{\mathrm{c}}$ values.

\section{Results}

246 The collection of enamel samples from dental clinics across MV resulted in a globally

247 represented dataset including 14 countries (Figure 1) reflecting the regional district's high

248 fluidity in international migrations ${ }^{52}$. Of the collected tooth samples, enough enamel powder was

249 generated from 103 samples for isotopic analysis. Two samples returned no oxygen isotopic

250 signatures signifying the absence of organic matter within the enamel, which could be attributed

251 to the presence of dental porcelain that is visually akin to dental enamel. City-level geographical

252 information could not be retrieved from 21 of the analyzed samples due to either missing

253 information or where individuals provided only the name of the country of residence. However,

254 one sample came from the Fiji Islands. While the exact city was not identified, it was included in

255 the study because of the country's relatively small size and as the only sample from Oceania.

256 Lastly, five samples came from individuals who had relocated to multiple locations during the

257 span of tissue formation and thus could not be associated with any single city, resulting in a total 258 of 75 samples with reliable geographical associations. 
260 A summary of $\delta^{18} \mathrm{O}_{\mathrm{c}}$ results for all analyzed samples is provided as Supplementary Table S1

261 online along with the corresponding mean $\delta{ }^{18} \mathrm{O}_{\mathrm{dw}}$ values taken from other published studies for

262 the city of residence, $\square{ }^{18}$ OoIPC and $\square{ }^{18}$ OrCwIP values. The estimated $\square{ }^{18}$ OoIPC and $\square{ }^{18}$ OrCwIP

263 values were not statistically significantly different as per the pairwise t-test $[\mathrm{t}(74)=-0.747$,

$264 \mathrm{df}=74, \mathrm{p}=0.457]$, and thus only the estimated values from the OIPC were used for subsequent

265 analyses.

266

$267 \delta^{18} \boldsymbol{O}_{c}$ and $\delta^{18} \boldsymbol{O}_{\text {tap }}$ results for $M V$

26824 individuals were of MV origin and covered eight municipalities-Burnaby, Coquitlam,

269 Langley, Richmond, New Westminster, North Vancouver, Surrey, and Vancouver (Figure 2). $\delta$

$270{ }^{18} \mathrm{O}_{\mathrm{c}(\mathrm{VPDB})}$ values ranged from $-11.0 \%$ (Burnaby) to $-7.2 \%$ (Surrey) with a mean value of

$271-8.7 \% \pm 0.8$ (Figure 3a). One-way ANOVA test showed no statistically significant inter-city

272 differences between mean $\delta^{18} \mathrm{O}_{\mathrm{c}(\mathrm{VPDB})}$ values $[\mathrm{F}(7,16)=0.717, \mathrm{p}=6.59]$. Further, no statistically

273 significant differences were observed for mean $\delta^{18} \mathrm{O}_{\mathrm{c}(\mathrm{VPDB})}$ values when data was disaggregated

274 by tap water source $[\mathrm{F}(4,19)=1.013, \mathrm{p}=0.426]$ (Figure 3b); however, an outlier was identified

275 for the sample with $\delta^{18} \mathrm{O}_{\mathrm{c}(\mathrm{VPDB})}$ value of $-11.0 \%$. The $\mathrm{MV} \delta{ }^{18} \mathrm{O}_{\mathrm{c}(\mathrm{VPDB})}$ range then becomes

$276-9.7 \%$ to $-7.2 \%$ when the outlier is excluded.

277

278 Monthly $\delta^{18} \mathrm{O}_{\text {tap }}$ values ranged from $-13.0 \%$ to $-8.2 \%$ with an annual mean of $-11.1 \%$ ( $\left.\mathrm{n}=22\right)$

279 and $-13.2 \%$ to $-8.5 \%$ with an annual mean of $-11.7 \%$ ( $=23)$ for MV tap waters treated at

280 CWTP and SCFP, respectively (Figure 4). Fractional contributions of each major MV tap water

Updated: March 17, 2021 
281 source to the overall municipal water supply were calculated for all municipalities represented by

282 the enamel samples (Table 3).

283

284 The OLS regression for MV $\delta^{18} \mathrm{O}_{\mathrm{c}}$ and $\delta^{18} \mathrm{O}_{\text {tap }}$ values yielded the result:

$\delta^{18} \mathrm{O}_{\mathrm{c}(\mathrm{VSMOW})}=0.10( \pm 0.75) \times \delta^{18} \mathrm{O}_{\mathrm{tap}(\mathrm{VSMOW})}+23.08( \pm 8.58) ;\left[\mathrm{df}=22 ; \bar{R}^{2}=-0.04\right]$

286 The negative $\bar{R}^{2}$ value indicates that, statistically, the data cannot be explained by the model.

\section{$\delta^{18} O_{c}$ results for Canada}

289 In addition to the 24 individuals from MV, four individuals were from BC cities outside of MV, 290 two from Manitoba (MB), seven from Ontario (ON), and two from Quebec (QC) (Figure 5). The 291 mean $\delta^{18} \mathrm{O}_{\mathrm{c}(\mathrm{VPDB})}$ value for $\mathrm{BC}$ was similar to $\mathrm{MV}$ at $-8.7 \%$

$292{ }^{18} \mathrm{O}_{\mathrm{c}(\mathrm{VPDB})}$ value for all Canadian samples was also similar at $-8.7 \%$ \% $\pm 1.1(\mathrm{n}=41)$ with a range 293 of $-11.0 \%$ (Burnaby, BC) to $-5.3 \%$ (Hamilton, ON). One-way ANOVA test showed no 294 statistically significant differences between provinces $[F(3,35)=0.825, p=0.489]$. Cities 295 supplied by Lake Ontario showed the largest range in $\delta^{18} \mathrm{O}_{\mathrm{c}(\mathrm{VPDB})}$ values from $-10.6 \%$ to $2965.3 \%$ compared to other water sources from across Canada.

298 Source water information was retrieved for each represented city ${ }^{39,53-58}$. No source water 299 information could officially be retrieved for Chapeau, QC, but the most probable water source 300 was identified to be Ottawa River ${ }^{59}$. Modern $\square{ }^{18} \mathrm{O}_{\text {tap }}$ data were found for Hamilton, St.

301 Catharines, Toronto ${ }^{60}$, and Winnipeg ${ }^{61}$ with given source information (see Supplementary Table

302 S2 online). $\square{ }^{18}$ Otap data for Ottawa was taken for both Chapeau and Morin Heights as no Updated: March 17, 2021 
$303{ }^{18} \mathrm{O}_{\text {tap }}$ data were found for the two cities. Ottawa River supplies both Chapeau and Morin

304 Heights, and which also is the water source for Ottawa. Only surface water values were found for

305 the drinking water sources of Kelowna ${ }^{62}$, Prince George, and Vanderhoof ${ }^{63}$, and no $\square{ }^{18} \mathrm{O}_{\mathrm{dw}}$

306 values were associated with Williams Lake and Baysville.

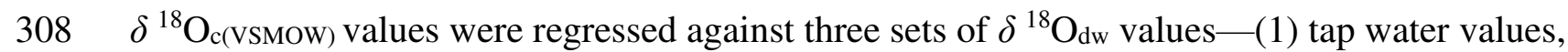

309 (2) tap water and surface water or groundwater values $\left(\delta^{18} \mathrm{O}_{\mathrm{dw} \_}\right)$, and (3) a combined set of tap

310 water, surface water or groundwater and OIPC values $\left(\delta^{18} \mathrm{O}_{\mathrm{dw} \_} 2\right)$ (Figure 6) because not all

311 samples could be directly paired with modern $\square{ }^{18} \mathrm{O}_{\text {tap }}$ values.

$312 \delta{ }^{18} \mathrm{O}_{\mathrm{c}(\mathrm{VSMOW})}=0.11( \pm 0.09) \times \delta^{18} \mathrm{O}_{\mathrm{tap}(\mathrm{VSMOW})}+23.29( \pm 0.98) ;\left[\mathrm{df}=32 ; \bar{R}^{2}=0.01\right]$

$313 \delta{ }^{18} \mathrm{O}_{\mathrm{c}(\text { VSMOW })}=0.16( \pm 0.08) \times \delta^{18} \mathrm{O}_{\mathrm{dw}_{-} 1(\text { VSMOW })}+23.77( \pm 0.82) ; \quad\left[\mathrm{df}=35 ; \bar{R}^{2}=0.09\right]$

$314 \delta{ }^{18} \mathrm{O}_{\mathrm{c}(\text { VSMOw })}=0.15( \pm 0.07) \times \delta^{18} \mathrm{O}_{\mathrm{dw} \_2(\text { VSMOW })}+23.65( \pm 0.78) ; \quad\left[\mathrm{df}=37 ; \bar{R}^{2}=0.08\right]$

315 The Analysis of Covariance (ANCOVA) test was used to compare the three sets of linear

316 regressions to determine whether they significantly differ from each other. Results showed no

317 statistically significant differences between the three equations, $[F(2,106)=0.010, p=0.990]$.

318 Equation (3) with the highest $\bar{R}^{2}$ value proved to be the most reliable equation for Canada.

319 Overall, all three regressions showed a positive but weak linear relationship between $\square{ }^{18} \mathrm{O}_{\text {enam }}$ 320 and $\square{ }^{18} \mathrm{O}_{\mathrm{dw}}$ values for the Canadian samples.

\section{$322 \delta^{18} O_{c}$ results for the global dataset}

323 The remaining 36 samples included individuals from 13 additional countries encompassing the

324 latitudinal areas from 55.75124 (Moscow, Russia) to -17.71337 (Fiji Islands). The mean $\delta$ Updated: March 17, 2021 
$325{ }^{18} \mathrm{O}_{\mathrm{c}(\mathrm{VPDB})}$ values were more negative in comparison to Canada for all countries except for the 326 single enamel formed in Russia (Figure 7). There was a general latitudinal trend where $\delta^{18} \mathrm{O}_{\mathrm{c}}$

327 values increased with decreasing latitude, although with a large range at higher latitudes (Figure 328 8).

330 Tap water data were retrieved for China ${ }^{25,33,64}$, Hong Kong ${ }^{33,64}$, Iran, Kazakhstan, Kenya ${ }^{64}$, 331 Malaysia $^{65}$, Mexico, Russia, and Vietnam ${ }^{64}$ (see Supplementary Table 2 online). While tap water 332 data was available for New Delhi, India ${ }^{64,66}$, only groundwater values could be retrieved for 333 Kolkata, India ${ }^{64}$. No tap water value was found for Kitwe, Zambia; however, surface water data 334 of Kafue River, which is the drinking water source for Kitwe ${ }^{67}$, was retrieved ${ }^{68}$. No such data 335 were found for Fiji, Japan, and for Yiyuan, Zibo in China.

337 The OLS regression for $\delta{ }^{18} \mathrm{O}_{\mathrm{c}}$ and $\delta{ }^{18} \mathrm{O}_{\text {tap }}$ for the global dataset yielded the result (Figure 9):

$338 \delta^{18} \mathrm{O}_{\mathrm{c}(\mathrm{VSMOW})}=0.41( \pm 0.06) \times \delta^{18} \mathrm{O}_{\mathrm{tap}(\mathrm{VSMOW})}+26.55( \pm 0.55) ;\left[\mathrm{df}=63, \bar{R}^{2}=0.41\right]$

339 Similar to the Canadian dataset, $\delta{ }^{18} \mathrm{O}_{\mathrm{c}(\text { VSMOw) }}$ values were regressed against $\delta{ }^{18} \mathrm{O}_{\mathrm{dw} \_} 1$ (VSMOw), 340 and $\delta^{18} \mathrm{O}_{\mathrm{dw} \_} 2$ (VSMOw) values, as well as against $\delta^{18} \mathrm{OOIPC}_{\text {(VSMOW). }}$

$341 \delta^{18} \mathrm{O}_{\mathrm{c}(\text { VSMOW })}=0.39( \pm 0.05) \times \delta^{18} \mathrm{O}_{\mathrm{dw}_{-} 1(\mathrm{VSMOW})}+26.41( \pm 0.47) ;\left[\mathrm{df}=68, \bar{R}^{2}=0.45\right]$

$342 \delta^{18} \mathrm{O}_{\mathrm{c}(\mathrm{VSMOW})}=0.40( \pm 0.05) \times \delta^{18} \mathrm{O}_{\mathrm{dw} \_2(\mathrm{VSMOW})}+26.53( \pm 0.45) ;\left[\mathrm{df}=73, \bar{R}^{2}=0.47\right]$

$343 \delta^{18} \mathrm{O}_{\mathrm{c}(\mathrm{VSMOW})}=0.43( \pm 0.05) \times \delta^{18} \mathrm{OoIPC}_{(\mathrm{VSMOW})}+26.92( \pm 0.46) ;\left[\mathrm{df}=73, \bar{R}^{2}=0.51\right]$

344 The ANCOVA test showed no statistically significant differences between the four equations

$345[\mathrm{~F}(3,280)=0.144, \mathrm{p}=0.933]$. Of the four equations, equation (8) had the highest $\bar{R}^{2}$ value and thus 346 proved to be the most reliable equation for the global dataset.

Updated: March 17, 2021 


\section{Predictability of existing models}

349 The observed $\mathrm{MV} \delta^{18} \mathrm{O}_{\text {tap }}$ values were used to estimate the range of $\mathrm{MV} \delta^{18} \mathrm{O}_{\mathrm{c}}$ values through 350 existing predictive models and all equations derived in this study. Fars, Iran (MV007) and

351 Khuzestan, Iran (MV097) were identified to be from hot arid climates as specified by the 352 updated Koppen climate classification system ${ }^{69}$. They were converted to $\delta^{18} \mathrm{O}_{\mathrm{p}}$ values using the 353 equation given by Chenery et al. ${ }^{20}\left[\delta^{18} \mathrm{O}_{\mathrm{p}}=1.122 \delta^{18} \mathrm{O}_{\mathrm{c}}-13.73\right]$. The minimum MV tap water 354 value of $-11.7 \%$ was taken from annualized data of SCWT, and the maximum value of -9.3 355 was reported in Ueda and Bell ${ }^{35}$ with a groundwater source. The range of values estimated by 356 Dotsika's ${ }^{70}$ equation provided the most accurate estimate where $91.7 \%$ of MV individuals were 357 correctly identified to have resided in MV during their childhood years. 15 combinations of 358 models failed to identify any MV individuals accurately. The observed ranges of $\delta^{18} \mathrm{O}_{\mathrm{c}}$ values 359 for MV were generally more negative than predicted ranges from existing models except for 360 ranges predicted with Posey's ${ }^{71}$ equation (Figure 10).

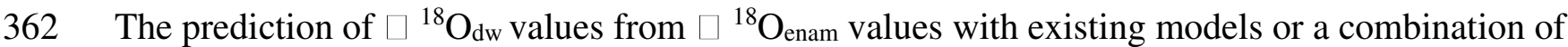
363 existing models (see Supplementary Table S3 online) resulted in a wide range of $\square{ }^{18} \mathrm{O}_{\mathrm{dw}}$ values 364 for each observed $\square{ }^{18} \mathrm{O}_{\mathrm{c}}$ measurement (Figure 11). The offset between predicted and observed 365 values ranged from -15.3 to $+5.5 \%$ for tap water (Figure $12 \mathrm{a}$ ) and -12.5 to $+6.5 \%$ for OIPC

366 (Figure 12b). The use of the equation given by Dotsika ${ }^{70}$ produced the least MSD between 367 predicted and observed drinking water values for both tap water measurements $(\mathrm{MSD}=4.00$;

$368 \mathrm{NU}=0.00 ; \mathrm{LC}=3.45 ; \mathrm{SB}=0.55)$ (Figure 13a) and OIPC measurements $(\mathrm{MSD}=3.72 ; \mathrm{NU}=0.07$; Updated: March 17, 2021 
$\mathrm{LC}=3.42 ; \mathrm{SB}=0.23$ ) (Figure 13b; see Supplementary Table S4 online). Equation (1) gave the

370 highest MSD for both tap water (MSD=278.21; $\mathrm{NU}=210.61 ; \mathrm{LC}=3.45 ; \mathrm{SB}=64.15)$ and OIPC

371 measurements $(\mathrm{MSD}=297.08 ; \mathrm{NU}=223.42 ; \mathrm{LC}=3.41 ; \mathrm{SB}=70.24)$.

\section{Discussion}

373 Results from MV enamel samples revealed no statistically significant differences in mean $\square{ }^{18} \mathrm{O}_{\mathrm{c}}$

374 values across the regional district regardless of the municipal tap water source differences. This

375 may be explained by the similarity in the annualized $\square{ }^{18} \mathrm{O}$ tap values of tap water treated at the

376 two main MV tap water treatment facilities-SCTF and CWTP - that treats approximately 95\%

377 of all tap water delivered to MV municipalities ${ }^{39}$. The sampled enamels were formed during the

378 period when an independent treatment facility had treated Capilano water. However, Capilano

$379 \quad{ }^{18} \mathrm{O}_{\text {tap }}$ values had shown significant overlap with Seymour $\square{ }^{18} \mathrm{O}_{\text {tap }}$ values before the construction

380 of the twin tunnels ${ }^{35}$. The isotopically homogeneous results across MV municipalities indicate

381 that human geolocation, based solely on $\square{ }^{18} \mathrm{O}_{\mathrm{c}}$ values, is difficult at the city-level for MV but

382 that a defined range of values exists for the entire regional district, which is now known to span

383 from $-9.7 \%$ to $-7.2 \%$. Notably, the understanding of such a defined range in values for MV

384 signifies the possibility of oxygen isotope analysis to be used as an exclusionary tool to identify

385 non-MV residents who fall outside of this defined range.

387 The range of annualized $\square{ }^{18} \mathrm{O}_{\text {tap }}$ values for MV (-11.7\% to $-9.3 \%$ ) includes groundwater 388 values presented in Ueda and Bell's ${ }^{35}$ study that are assumed to represent annualized water 389 although from a single sample. Given that the fractional contribution of ${ }^{18} \mathrm{O}_{\mathrm{dw}}$ to ${ }^{18} \mathrm{O}$ enam is $<1$, 
390 MV $\square{ }^{18} \mathrm{O}_{\mathrm{c}}$ values can be expected to have a smaller range than that of $\square{ }^{18} \mathrm{O}_{\mathrm{dw}}$ values. However,

391 the exact estimation of this range is dependent on which combination of existing predictive

392 models are applied. The predicted MV $\square{ }^{18} \mathrm{O}_{\text {enam }}$ values generally were positively biased except

393 for the values predicted from Dotsika's ${ }^{70}$ equation which showed very good predictability.

394 Dotsika's equation was developed based on a country-level analysis of modern human samples

395 from Greece with known $\square{ }^{18} \mathrm{O}_{\mathrm{dw}}$ values.

397 Sampling across MV enabled the collection of a globally represented set of samples due to the 398 regional district's high fluidity in both national and international migration ${ }^{52}$. Notably, $\square{ }^{18} \mathrm{O}_{c}$ 399 values in known modern samples from the entire MV region showed a distinct separation from 400 other B.C. cities (Prince George and Vanderhoof) located at higher latitudes and signifies the 401 possibility of utilizing oxygen isotope analysis to distinguish MV from northern B.C. cities. 402 However, overlaps in $\square{ }^{18} \mathrm{O}_{\mathrm{c}}$ values were observed between other Canadian cities regardless of 403 the latitudinal differences (Figure 6). A general latitudinal trend can, however, be observed when 404 looking at the global enamel dataset. Mean Canadian $\square{ }^{18} \mathrm{O}_{\mathrm{c}}$ values were slightly more negative 405 compared to $\square{ }^{18} \mathrm{O}_{\mathrm{c}}$ values from individuals residing in other parts of the world during the time 406 of enamel formation, although with increasing overlap for the more positive $\square{ }^{18} \mathrm{O}_{\mathrm{c}}$ values. This 407 again underscores this oxygen-isotope tool's potential to be used as an exclusionary method for 408 identifying individuals with a non-Canadian origin when $\square{ }^{18} \mathrm{O}_{\mathrm{c}}$ values fall outside the Canadian 409 range. 
411 Equation (8) showed the highest $\bar{R}^{2}$, where $\square{ }^{18} \mathrm{O}_{\mathrm{dw}}$ values were calculated with the OIPC for the

412 global dataset. In comparison, equation (1) had the lowest $\bar{R}^{2}$ but with the highest geographical

413 resolution. The model performed better as the geographical resolution decreased from city to

414 country to a global dataset. This indicates that a positive relationship between ${ }^{18} \mathrm{O}_{\text {enam }}$ and ${ }^{18} \mathrm{O}_{\mathrm{dw}}$

415 exists at the global level, with precipitation most heavily influencing $\square{ }^{18} \mathrm{O}_{\mathrm{c}}$ values. Perhaps such

416 an observation can be explained by the influence of precipitation on the overall drinking water

417 systems. The lower $\bar{R}^{2}$ from MV and Canadian samples may also be due to the complexity in

418 determining the fractional contributions of each water source to consumed water. The

419 interconnectedness of MV water pipes reduces community dependence on a single water source.

420 It enables water distribution from alternative sources during water shortage or contamination,

421 which can change by the hour.

422

423 If it is true that a single line can represent the ${ }^{18} \mathrm{O}_{\mathrm{c}}$ and ${ }^{18} \mathrm{O}_{\mathrm{dw}}$ relationship, then the degree to

424 which one relates to the other should be independent of geographical resolution. Globally

425 constructed predictive models should then be applied with caution and with the understanding

426 that there is a possibility of individuals deviating from the predicted regression line, especially

427 when attempting to geolocate individuals on a smaller geographical scale. Additionally, the ${ }^{18} \mathrm{O}_{\mathrm{c}}$

428 and ${ }^{18} \mathrm{O}_{\mathrm{dw}}$ relationship simplification can incorrectly lead to the assumption that regional areas

429 with a common $\square{ }^{18} \mathrm{O}_{\text {ppt }}$ or $\square^{18} \mathrm{O}_{\text {tap }}$ value translates to a single $\square^{18} \mathrm{O}_{\mathrm{c}}$ value. Like MV, enamel

430 samples formed in Hong Kong showed a wide range of $\square{ }^{18} \mathrm{O}_{\mathrm{c}}$ values, which only became

431 evident with the concentrated number of individuals within our sample set that had resided in

Updated: March 17, 2021 
432 Hong Kong during the time of tissue formation. Other cities may show such a spread in $\square{ }^{18} \mathrm{O}_{\mathrm{c}}$ 433 values, which can only be understood with a high-resolution study.

435 Overall, the equations derived from this study reveal a smaller fractional contribution of ${ }^{18} \mathrm{O}_{\mathrm{dw}}$ to

$436{ }^{18} \mathrm{O}_{\text {enam }}$ compared to existing water to enamel models. The equations from the global dataset

437 (equations 5 to 8 ) were more comparable to other predictive models than those derived from 438 higher geographical resolutions (equations 1 to 4). Equation (8) with the highest $\bar{R}^{2}$ was most 439 comparable to Levinson et al's ${ }^{13}$ equation.

441 Dotsika's ${ }^{70}$ equation proved to best predict $\delta^{18} \mathrm{O}_{\mathrm{dw}}$ from $\delta^{18} \mathrm{O}_{\mathrm{c}}$ values with the lowest mean 442 standard deviation of 4.00 for tap water and 3.72 for OIPC. Again, this could be attributed to the 443 care taken in the sampling of known data from across Greece with the pairing of known drinking 444 water data. The equations that showed the least accuracies were those from this current study 445 (equations 1 to 4 ) with large NU components. NU is a direct measure of the slope where NU>0 446 when the slope $\neq 1^{51}$, it may be deduced to reflect observed differences in the measured 447 fractional contributions of ${ }^{18} \mathrm{O}_{\mathrm{dw}}$ to ${ }^{18} \mathrm{O}$ c. Importantly, however, is to note that individuals from a 448 constrained geographical region can show wide ranges in $\delta^{18} \mathrm{O}_{\mathrm{c}}$ values, which may lead to low 449 correlation measures with drinking water samples, such as was the case for MV. This range of $450 \quad \delta^{18} \mathrm{O}_{c}$ values specific to its region can only be understood through concentrated sampling and 451 analysis of a large number of individuals from that same region. Therefore, large NU measures 452 do not necessarily translate to differences in measures of ${ }^{18} \mathrm{O}_{\mathrm{dw}}$ to ${ }^{18} \mathrm{O}_{\mathrm{c}}$ fractional contributions 
453 but rather that the true range of $\delta^{18} \mathrm{O}_{\mathrm{c}}$ values became known and that perhaps it is not possible to

454 measure the direct relationships simply by linear regression.

456 Daux et al.'s ${ }^{9}$ equation paired with Iacumin et al.'s ${ }^{19}$ equation (D5I) showed the largest MSD

457 amongst the existing predictive models and scored high on SB (Figure 13). SB> 0 when intercept

$458 \neq 0$ and thus reflects the vertical shifting of a function. High SB measures could be a reflection of

459 inter-laboratory differences. Inter-laboratory differences between $\delta^{18} \mathrm{O}_{\mathrm{p}}$ values, as discussed by

460 Chenery et al. ${ }^{72}$ are generally related to bio-phosphate preparation with either $\mathrm{BiPO}_{4} \mathrm{Or}_{\mathrm{Ag}_{3} \mathrm{PO}_{4}}$

461 prior to oxygen extraction. Chenery et al. concluded that a correction of 1.4 to Levinson et al.'s ${ }^{13}$

462 equation is required to best predict local $\delta^{18} \mathrm{O}_{\mathrm{dw}}$ values as measured through the U.K. drinking

463 water isoscapes. However, MSD calculations for this study showed contrary results to Levinson

464 et al.'s original equation, which performed better for known modern samples measured for

465 carbonate oxygen than that of Chenery et al.'s corrected Levinson's equation. SB measures were

466 generally lower for equations derived from carbonate oxygen analysis and those derived from

467 phosphate oxygen prepared with $\mathrm{BiPO}_{4}$. In contrast, equations derived from phosphate oxygen

468 prepared with $\mathrm{Ag}_{3} \mathrm{PO}_{4}$ had larger $\mathrm{SB}$ measures, as were the case for Daux et al.'s equations.

470 Differences in the predicted and observed $\delta^{18} \mathrm{O}_{\mathrm{dw}}$ values were as high as $15 \%$, where differences

471 increased with decreasing $\delta^{18} \mathrm{O}_{\mathrm{c}}$ values (Figure 12). Whereas the differences between predicted

472 and observed $\delta^{18} \mathrm{O}_{\mathrm{dw}}$ values generally fell within $\pm 5 \%$ for $\delta^{18} \mathrm{O}_{\mathrm{c}}$ values of 25 to $28 \%$, greater

473 differences were observed for lower $\delta^{18} \mathrm{O}_{c}$ values, with the highest difference observed for a

474 sample with $\delta^{18} \mathrm{O}_{\mathrm{c}}$ value of $-20 \%$. Inter-laboratory differences between $\delta^{18} \mathrm{O}_{\mathrm{c}}$ values measured

Updated: March 17, 2021 
475 at three separate laboratories using different methodologies and instruments were $<1 \%$ for

476 carbonate in tooth enamel ${ }^{17}$. Chesson et al. ${ }^{73}$ further tested for interlaboratory differences of

477 enamel oxygen from the same set of samples analyzed a few years apart. The differences were

478 mainly attributed to sample preparation and concluded that isotopic differences $>1.6 \%$ should

479 be considered meaningful. The potential bias associated with inter-laboratory differences in

480 sample preparation, methodology, and the choice of instruments, will further be compounded in

481 the calculations of $\delta^{18} \mathrm{O}_{\mathrm{dw}}$ values using $\delta^{18} \mathrm{O}_{\mathrm{c}}$ to $\delta^{18} \mathrm{O}_{\mathrm{dw}}$ conversion equations. The compounding

482 factor is dependent on the slope of the applied $\delta^{18} \mathrm{O}_{\mathrm{c}}$ to $\delta^{18} \mathrm{O}_{\mathrm{dw}}$ equation. For example,

483 Ehleringer's ${ }^{5}$ equation with a slope of 1.12 would translate to a maximum of $1.8 \%$ difference in $484 \delta^{18} \mathrm{O}_{\mathrm{dw}}$ values that may be associated with inter-laboratory differences. Ehleringer's equation 485 showed high offsets between observed $\delta^{18} \mathrm{O}_{\mathrm{dw}}$ values and predicted $\delta^{18} \mathrm{O}_{\mathrm{dw}}$ values for individuals 486 with relatively more negative $\delta^{18} \mathrm{O}_{\mathrm{c}}$ values. Such large differences beyond what can be explained 487 by the possible inter-laboratory differences can be concluded to be important.

489 Differences in slope and intercept of existing equations may be attributed to various

490 methodological approaches, such as in the types of sampled tissues in which the equations were 491 based upon, the period of tissue formation, the spatial resolution of collection sites $5,7,9,13-15,72$

492 (Table 4). For example, one of the early models given by Longinelli ${ }^{15}$ was based on 493 measurements of human bone bioapatite rather than on human enamel. Some studies lacked 494 information on the specific types of sampled tooth ${ }^{13,14}$ while others studied archaeological or 495 forensic samples with inferred geographical information where drinking water sources may be 496 unknown. $\square{ }^{18}$ Oenam values can also be represented through the analysis of carbonate or Updated: March 17, 2021 
497 phosphate oxygen. Another key notable difference is in the definition of the term "drinking

498 water". $\square{ }^{18} \mathrm{O}_{\mathrm{dw}}$ values were measured from various sources, including meteoric water, predicted

499 precipitation water, well water, tap water, or a mixture of the above. Thus, inter-laboratory

500 differences cannot fully explain the observed differences between estimated drinking water

501 values.

502

503 The reliability of predictive models is premised on the degree to which the human tissues can be 504 assigned to a geographical locale and the understanding of the true source of drinking water in 505 which the individual had consumed during the time of tissue formation. Models should then be 506 based on the oxygen analysis of modern human enamel with known geographical information for 507 the period in which tissue formed for the pairing with appropriate $\delta^{18} \mathrm{O}_{\mathrm{dw}}$ data. The preferred 508 study is of known modern samples where geographical information can be obtained directly 509 from the living donor over unknown or archaeological samples where inference of these types of 510 information is required. Drinking water data should also be thoroughly examined as tap water

511 with known source information can best provide the most accurate drinking water data.

513 Large offsets in predicted values can lead to significant errors when inferring an individual's 514 geographical movement for identification purposes. The results support the recommendation to 515 standardize the methodology for the development of $\delta^{18} \mathrm{O}_{\mathrm{dw}}$ to $\delta^{18} \mathrm{O}_{\text {enam }}$ equations, as stated in 516 other papers ${ }^{17,73}$. There is undeniably a much-needed refinement in the current predictive models 517 and a need for consensus across the forensic community as to which predictive model is most 518 appropriate for human provenancing. The alternative empirical approach to using predictive Updated: March 17, 2021 
519 models for human provenancing recommended by several studies may be the more appropriate

520 methodology for mapping human origin through stable oxygen isotopes. This approach involves

521 the direct mapping of tissue isotopes themselves ${ }^{7,8}$ and limits the introduction of errors

522 associated with predictive models. The development of such tissue-specific isotope maps will

523 allow for a direct comparison of samples to reliable reference datasets.

\section{Conclusion}

525 This study aimed to assess the relationships between known bio-geographical enamel data to 526 known city-wide drinking water data. Results indicate that although weak, there is a positive

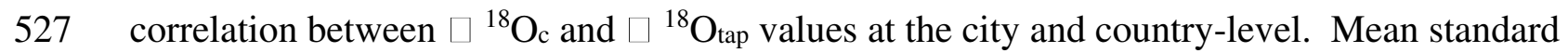
528 deviations measurements were carried out to assess the predictability of existing conversion 529 models. The equation provided by Dotsika ${ }^{70}$ proved to be the best model for this current set of 530 enamel data. However, large differences between actual and predicted $\delta^{18} \mathrm{O}_{\mathrm{dw}}$ values were noted

531 depending on the conversion equation or combination of conversion equations published in the

532 literature. Thus, this study supports the development of tissue-specific $\square{ }^{18} \mathrm{O}_{\mathrm{c}}$ geographical

533 reference maps. Standardization of methodology for isotopic analysis is also vital for the

534 collaborative collection of globally represented data. The development of international $\square{ }^{18} \mathrm{O}_{\text {enam }}$

535 databases would ultimately render conversion equations unnecessary and eliminate any

536 associated errors. A meaningful approach would be to define boundaries confined by the tap

537 water distribution systems rather than by way of political borders, which can be made possible

538 with the detailed understanding of tap water supply and distribution systems for any given

539 geographical area. The development of a reliable database would greatly benefit the forensic

Updated: March 17, 2021 
540 community by providing accurate guidance for unidentified individuals' possible region-of-

541 origin determination. The understanding of the city-specific range of $\square{ }^{18} \mathrm{O}_{\mathrm{c}}$ values for Metro

542 Vancouver ( $-9.7 \%$ to $-7.2 \%$ ) now allows for oxygen isotope analysis to be used as an

543 exclusionary tool where individuals with $\square{ }^{18} \mathrm{O}_{\mathrm{c}}$ values that exceed threshold values can be

544 identified as non-local. Such a tool is vital for assisting the forensic community in missing

545 persons investigations.

\section{Data availability}

547 All data analysed during the current study are available from the corresponding authors on 548 reasonable request.

\section{References}

550 1. Ehleringer, J. R. et al. Hydrogen and oxygen isotope ratios in human hair are related to 551 geography. Proc. Natl. Acad. Sci. U. S. A. 105, 2788-2793 (2008).

552 2. Font, L., van der Peijl, G., van Leuwen, C., van Wetten, I. \& Davies, G. R. Identification 553 of the geographical place of origin of an unidentified individual by multi-isotope analysis.

$554 \quad$ Sci. Justice 55, 34-42 (2015).

555 3. Bowen, G. J. \& Wilkinson, B. Spatial distribution of $\delta^{18} \mathrm{O}$ in meteoric precipitation.

$556 \quad$ Geology 30, 315-318 (2002).

557 4. Warner, M. M., Plemons, A. M., Herrmann, N. P. \& Regan, L. A. Refining Stable Oxygen

558 and Hydrogen Isoscapes for the Identification of Human Remains in Mississippi,. $J$.

$559 \quad$ Forensic Sci. (2018) doi:10.1111/1556-4029.13575.

560 5. Ehleringer, J. R. et al. A Framework for the Incorporation of Isotopes and Isoscapes in Updated: March 17, 2021 
Geospatial Forensic Investigations. in Isoscapes SE - 17 (eds. West, J. B., Bowen, G. J., Dawson, T. E. \& Tu, K. P.) 357-387 (Springer Netherlands, 2010). doi:10.1007/978-90481-3354-3_17.

564 6. Wunder, M. B. Using Isoscapes to Model Probability Surfaces for Determining Geographic Origins BT - Isoscapes: Understanding movement, pattern, and process on Earth through isotope mapping. in (eds. West, J. B., Bowen, G. J., Dawson, T. E. \& Tu, K. P.) 251-270 (Springer Netherlands, 2010). doi:10.1007/978-90-481-3354-3_12.

$5687 . \quad$ Pollard, A. M., Pellegrini, M. \& Lee-Thorp, J. A. Technical note: some observations on 569 the conversion of dental enamel $\delta^{18} \mathrm{O}_{(\mathrm{p})}$ values to $\delta^{18} \mathrm{O}_{(\mathrm{w})}$ to determine human mobility. Am. $570 \quad$ J. Phys. Anthropol. 145, 499-504 (2011).

571 8. Bell, L. S., Lee-Thorp, J. A. \& Elkerton, A. Sailing against the wind. J. Archaeol. Sci. 37, $572 \quad 683-686(2010)$.

573 9. Daux, V. et al. Oxygen isotope fractionation between human phosphate and water 574 revisited. J. Hum. Evol. 55, 1138-47 (2008).

575 10. Glick, P. L. Patterns of enamel maturation. J. Dent. Res. 58, 883-895 (1979).

576 11. Lacruz, R. S., Habelitz, S., Wright, J. T. \& Paine, M. L. Dental enamel formation and 577 implications for oral health and disease. Physiol. Rev. 97, 939-993 (2017).

578 12. Lee-Thorp, J. Two decades of progress towards understanding fossilization processes and 579 isotopic signals in calcified tissue minerals. Archaeometry 44, 435-446 (2002).

580 13. Levinson, A. A., Luz, B. \& Kolodny, Y. Variations in oxygen isotopic compositions of 581 human teeth and urinary stones. Appl. Geochemistry 2, 367-371 (1987).

582 14. Luz, B., Kolodny, Y. \& Horowitz, M. Fractionation of oxygen isotopes between Updated: March 17, 2021 
mammalian bone-phosphate and environmental drinking water. Geochim. Cosmochim. Acta 48, 1689-1693 (1984).

585 15. Longinelli, A. Oxygen isotopes in mammal bone phosphate: A new tool for paleohydrological and paleoclimatological research? Geochim. Cosmochim. Acta 48, 385390 (1984).

16. Sponheimer, M. \& Lee-Thorp, J. A. Oxygen isotopes in enamel carbonate and their ecological significance. J. Archaeol. Sci. (1999) doi:10.1006/jasc.1998.0388.

17. Demény, A., Gugora, A. D., Kesjár, D., Lécuyer, C. \& Fourel, F. Stable isotope analyses of the carbonate component of bones and teeth: The need for method standardization. $J$. Archaeol. Sci. 109, 104979 (2019).

18. Bryant, D., Koch, P. L., Froelich, P. N., Showers, W. J. \& Genna, B. J. Oxygen isotope partitioning between phosphate and carbonate in mammalian apatite. Geochim. Cosmochim. Acta 60, 5145-5148 (1996).

596 19. Iacumin, P., Bocherens, H., Mariotti, A. \& Longinelli, A. Oxygen isotope analyses of coexisting carbonate and phosphate in biogenic apatite: a way to monitor diagenetic alteration of bone phosphate? Earth Planet. Sci. Lett. 142, 1-6 (1996).

599 20. Chenery, C. A., Pashley, V., Lamb, A. L., Sloane, H. J. \& Evans, J. A. The oxygen isotope 600 relationship between the phosphate and structural carbonate fractions of human bioapatite. 601 Rapid Commun. Mass Spectrom. 26, 309-319 (2012).

602 21. Wright, L. E., Valdés, J. A., Burton, J. H., Douglas Price, T. \& Schwarcz, H. P. The 603 children of Kaminaljuyu: Isotopic insight into diet and long distance interaction in Mesoamerica. J. Anthropol. Archaeol. 29, 155-178 (2010).

Updated: March 17, 2021 
605 22. Podlesak, D. W., Bowen, G. J., O’Grady, S., Cerling, T. E. \& Ehleringer, J. R. $\delta^{2} H$ and

$606 \quad \delta^{18} \mathrm{O}$ of human body water: A GIS model to distinguish residents from non-residents in the contiguous USA. Isotopes Environ. Health Stud. (2012) doi:10.1080/10256016.2012.644283.

23. Gretebeck, R. J. et al. Adaptation of the doubly labeled water method for subjects consuming isotopically enriched water. J. Appl. Physiol. 82, 563-570 (1997).

611 24. Tipple, B. J. et al. Stable hydrogen and oxygen isotopes of tap water reveal structure of the San Francisco Bay Area’s water system and adjustments during a major drought. Water Res. 119, 212-224 (2017).

614 25. Wang, S. et al. Water Source Signatures in the Spatial and Seasonal Isotope Variation of 615 Chinese Tap Waters. Water Resour. Res. 54, 9131-9143 (2018).

616 26. Ghassemi, F. \& White, I. Inter-Basin Water Transfer : Case Studies from Australia, 617 United States, Canada, China and India. (Cambridge University Press, 2007).

618 27. World Health Organization. Progress on sanitation and drinking water: 2010 Update. 619 http://apps.who.int/iris/bitstream/10665/81245/1/9789241505390_eng.pdf (2013).

620 28. Good, S. P. et al. Patterns of local and nonlocal water resource use across the western U.S. 621 determined via stable isotope intercomparisons. Water Resour. Res. 2108-2123 (2014) 622 doi:10.1002/2012WR013085.Received.

623 29. Bowen, G. J., Ehleringer, J. R., Chesson, L. A., Stange, E. \& Cerling, T. E. Stable isotope 624 ratios of tap water in the contiguous United States. Water Resour. Res. 43, 1-12 (2007).

625 30. Chesson, L. A. et al. Strontium isotopes in tap water from the coterminous USA. $626 \quad$ Ecosphere 3, art67 (2012).

Updated: March 17, 2021 
627 31. Ammer, S. T. M., Bartelink, E. J., Vollner, J. M., Anderson, B. E. \& Cunha, E. M. Spatial

628 Distributions of Oxygen Stable Isotope Ratios in Tap Water From Mexico for Region of

629 Origin Predictions of Unidentified Border Crossers ,. J. Forensic Sci. 65, 1049-1055

$630 \quad$ (2020).

631 32. West, A. G., February, E. C. \& Bowen, G. J. Spatial analysis of hydrogen and oxygen

632 stable isotopes ("isoscapes") in ground water and tap water across South Africa. $J$.

633 Geochemical Explor. 145, 213-222 (2014).

634 33. Zhao, S. et al. Divergence of stable isotopes in tap water across China. Sci. Rep. 7, 43653

$635 \quad$ (2017).

636 34. Jameel, Y. et al. Tap water isotope ratios reflect urban water system structure and

637 dynamics across a semiarid metropolitan area. Water Resour. Res. 52, 5891-5910 (2016).

638 35. Ueda, M. \& Bell, L. S. A City-wide Investigation of the Isotopic Distribution and Source

639 of Tap Waters for Forensic Human Geolocation Ground-truthing. J. Forensic Sci. 62,

$640 \quad 655-667(2017)$.

641 36. Metro Vancouver. Watershed Education. Metro Vancouver

642 http://public.metrovancouver.org/region/teachers/fieldtrips/Pages/lscr.aspx (2014).

643 37. Lee-Thorp, J., Manning, L. \& Sponheimer, M. Problems and prospects for carbon isotope

644 analysis of very small samples of fossil tooth enamel. Bull. Geol. Soc. Fr. 168, 767-773

$645 \quad$ (1997).

646 38. Coplen, T. B. Guidelines and recommended terms for expression of stable-isotope-ratio

647 and gas-ratio measurement results. Rapid Commun. Mass Spectrom. 25, 2538-2560

$648 \quad(2011)$.

Updated: March 17, 2021 
649 39. Metro Vancouver. Water Treatment \& Supply. Metro Vancouver http://www.metrovancouver.org/services/water/Pages/default.aspx (2020).

651 40. Bowen, G. J. The Online Isotopes in Precipitation Calculator, version 3.1. (2018).

652 41. Terzer, S., Wassenaar, L. I., Araguás-Araguás, L. J. \& Aggarwal, P. K. Global isoscapes 653 for $\delta 18 \mathrm{O}$ and $\delta 2 \mathrm{H}$ in precipitation: improved prediction using regionalized climatic regression models. Hydrol. Earth Syst. Sci. Discuss. (2013) doi:10.5194/hessd-10-73512013.

656 42. International Atomic Energy Agency. International Atomic Energy Agency: RCWIP (Regionalized Cluster-Based Water Isotope Prediction) Model - gridded precipitation $\delta^{18} \mathrm{O}\left|\delta^{2} \mathrm{H}\right| \delta^{18} \mathrm{O}$ and $\delta^{2} \mathrm{H}$ isoscape data. http://www.iaea.org/water (2014).

659 43. IAEA/WMO. Global Network of Isotopes in Precipitation. http://www.iaea.org/water 660 (2020).

661 44. Gujarati, D. N. Linear Regression: A Mathematical Introduction. (2019)

662 doi:10.4135/9781071802571.

663 45. Coplen, T. B. Normalization of oxygen and hydrogen isotope data. Chem. Geol. Isot. 664 Geosci. Sect. 72, 293-297 (1988).

665 46. Kruskal, W. H. \& Wallis, W. A. Use of Ranks in One-Criterion Variance Analysis. J. Am. $666 \quad$ Stat. Assoc. 47, 583-621 (1952).

667 47. Shapiro, S. S. \& Wilk, M. B. An Analysis of Variance Test for Normality (Complete 668 Samples). Biometrika 52, 591-611 (1965).

669 48. R Core Team. R: A language and environment for statistical computing. (2018).

670 49. Piñeiro, G., Perelman, S., Guerschman, J. P. \& Paruelo, J. M. How to evaluate models: Updated: March 17, 2021 
Observed vs. predicted or predicted vs. observed? Ecol. Modell. 216, 316-322 (2008).

672 50. Kobayashi, K. \& Salam, M. U. Comparing Simulated and Measured Values Using Mean

673 Squared Deviation and its Components. Agron. J. 92, 345-352 (2000).

674 51. Gauch, H. G., Hwang, J. T. G. \& Fick, G. W. Model Evaluation by Comparison of ModelBased Predictions and Measured Values. Agron. J. 95, 1442-1446 (2003).

676 52. Metro Vancouver. Metro Vancouver Growth Projections - A Backgrounder. http://www.metrovancouver.org/services/regionalplanning/PlanningPublications/OverviewofMetroVancouversMethodsinProjectingRegiona 1Growth.pdf (2018).

53. City of Kelowna. City of Kelowna Water. City of Kelowna http://www.kelowna.ca/cm/page393.aspx (2009).

682 54. City of Prince George. Water and Watersheds. https://www.princegeorge.ca/City 683 Services/Pages/Environment/WaterAndWatersheds.aspx (2017).

$68455 . \quad$ City of Winnipeg. Water and Waste Department.

685 http://www.winnipeg.ca/waterandwaste/water/default.stm (2017).

686 56. City of Toronto. Drinking Water.

687 http://www1.toronto.ca/wps/portal/contentonly?vgnextoid=e73cfe4eda8ae310VgnVCM10 $688 \quad$ 000071d60f89RCRD (2017).

689 57. Jacklin, J. Assessment of Vanderhoof South Drinking Water Supply: Source Water

$690 \quad$ Characteristics. https://www2.gov.bc.ca/assets/gov/environment/air-landwater/water/waterquality/water-quality-reference-documents/dwa-vanderhoof_south.pdf

692 (2005).

Updated: March 17, 2021 
693 58. Ministère du Développement durable de l'Environnement et de la Lutte contre les changements climatiques. Summary Profile of the Rivière des Outaouais Watershed. Bibliothèque et Archives nationales du Québec 57 http://www.environnement.gouv.qc.ca/eau/bassinversant/bassins/outaouais/portraitsommaire-en.pdf (2015).

698 59. Municipalité de L'Isle-aux-Allumettes. Municipality of L'Isle-Aux-Allumettes. http://www.isle-aux-allumettes.com/index-en.php (2012).

60. Mant, M., Nagel, A. \& Prowse, T. Investigating Residential History Using Stable Hydrogen and Oxygen Isotopes of Human Hair and Drinking Water. J. Forensic Sci. 61, 884-891 (2016).

61. Koehler, G. \& Hobson, K. A. Tracking cats revisited: Placing terrestrial mammalian carnivores on $\delta^{2} \mathrm{H}$ and $\delta^{18} \mathrm{O}$ isoscapes. PLoS One 14, e0221876 (2019).

62. Wassenaar, L. I., Athanasopoulos, P. \& Hendry, M. J. Isotope hydrology of precipitation,

708 63. Cameron, E. M., Hall, G. E. M., Veizer, J. \& Krouse, H. R. Isotopic and elemental 709 surface and ground waters in the Okanagan Valley, British Columbia, Canada. J. Hydrol.

711 64. Waterisotope Database. http://waterisotopesDB.org. (2019).

712 65. Mostapa, R., Ishak, A. K., Mohamad, K. \& Demana, R. Identification of bottled zam zam 713 water in malaysian market using hydrogen and oxygen stable isotope ratios $\left(\mathrm{d}^{2} \mathrm{H}\right.$ and $\mathrm{d}^{18}$ O). J. Nucl. Relat. Technol. 11, 48-53 (2014). 
715 66. Thompson, A. H. et al. Stable isotope analysis of modern human hair collected from Asia 716 (China, India, Mongolia, and Pakistan). Am. J. Phys. Anthropol. (2010)

717 doi:10.1002/ajpa.21162.

718 67. Katebe, R., Musukwa, G., Mweetwa, B., Shaba, P. \& Njovu, E. Assessment of Uranium in 719 Drinking Water in Kitwe, Chambeshi and Chingola in the Copperbelt Region of Zambia. $720 \quad$ (IAEA, 2015).

721 68. Zurbrügg, R., Wamulume, J., Kamanga, R., Wehrli, B. \& Senn, D. B. River-floodplain 722 exchange and its effects on the fluvial oxygen regime in a large tropical river system 723 (Kafue Flats, Zambia). J. Geophys. Res. Biogeosciences 117, (2012).

724 69. Kottek, M., Grieser, J., Beck, C., Rudolf, B. \& Rubel, F. World map of the Köppen725 Geiger climate classification updated. Meteorol. Zeitschrift (2006) doi:10.1127/0941$726 \quad 2948 / 2006 / 0130$.

727 70. Dotsika, E. Correlation between $\delta^{18} \mathrm{O}_{\mathrm{w}}$ and $\delta^{18} \mathrm{O}_{\mathrm{en}}$ for estimating human mobility and $728 \quad$ paleomobility patterns. Sci. Rep. 10, 15439 (2020).

729 71. Posey. Development and Validation of a Spatial Prediction Model for Forensic

730 Geographical Provenancing of Human Remains. (University of East Anglia, 2011).

731 72. Chenery, C., Müldner, G., Evans, J., Eckardt, H. \& Lewis, M. Strontium and stable 732 isotope evidence for diet and mobility in Roman Gloucester, UK. J. Archaeol. Sci. 37, $733 \quad 150-163(2010)$.

734 73. Chesson, L. A., Kenyhercz, M. W., Regan, L. A. \& Berg, G. E. Addressing data 735 comparability in the creation of combined data sets of bioapatite carbon and oxygen 736 isotopic compositions. Archaeometry 61, 1193-1206 (2019).

Updated: March 17, 2021 
737 74. Pye, K. Isotope and trace element analysis of human teeth and bones for forensic purposes. Geol. Soc. London, Spec. Publ. 232, 215-236 (2004).

\section{Acknowledgements}

742 We greatly appreciate Simon Fraser Dental, Dawson Dental Clinic and Surrey Place Dental

743 Group for their assistance in collecting dental samples, and Metro Vancouver for providing us

744 with monthly tap water samples from the Seymour-Capilano Filtration Plant and the Coquitlam

745 Water Treatment Plant. We would also like to express our appreciation to Richard Heemskerk of

746 University of Waterloo Environmental Isotopes Laboratory for the water analyses. We also thank

747 Erwin Kwok for laboratory assistance. LSB acknowledges financial support from the

$748 \mathrm{CFI} / \mathrm{BCKDF}$ and the SSHRC.

749

750 Author contributions

751 MU wrote the main manuscript text and prepared all figures. MU and LSB conceived research 752 design, analysed and interpreted results.

753

\section{$754 \quad$ Figure legends}

755 Figure 1. Locations of residence during tissue formation with the corresponding $\delta^{18} \mathrm{OC}(\mathrm{VPDB})$

756 values for all collected samples.

Updated: March 17, 2021 
758 Figure 2. Map of MV with the shaded areas representing sampled municipalities.

760 Figure 3. Boxplots of $\mathrm{MV} \delta^{18} \mathrm{O}_{\mathrm{C}}$ values as represented by a) city and b) tap water source. The

761 boxes represent $25^{\text {th }}$ and $75^{\text {th }}$ percentiles, and whiskers represent the maximum and minimum

762 observations. When outliers are present, the whiskers extend to 1.5 times the interquartile range.

763 The middle line denotes the median or $50^{\text {th }}$ percentile. One-way ANOVA tests showed no

764 statistically significant inter-city differences between mean $\delta^{18} \mathrm{O}_{\mathrm{c}}$ values for $\mathrm{MV}[\mathrm{F}(7,16)=$

$7650.717, \mathrm{p}=6.59]$, nor for mean $\mathrm{MV} \delta^{18} \mathrm{O}_{\mathrm{c}(\mathrm{VPDB})}$ values for data disaggregated by tap water source

$766 \quad[\mathrm{~F}(4,19)=1.013, \mathrm{p}=0.426]$.

767

768 Figure 4. Monthly MV tap water $\delta^{18} \mathrm{O}$ data for samples taken between June 2017 to May 2018 at

769 Coquitlam Water Treatment Plant (CWTP) and Seymour-Capilano Filtration Plant (SCFP).

770 Mean annual MV tap water $\delta^{18} \mathrm{O}$ values were $-11.1 \%$ and $-11.7 \%$ at CWTP and SCFP,

771 respectively.

772

773 Figure 5. Location of residence during tissue formation with the corresponding $\delta^{18} \mathrm{OC}_{\mathrm{C}(\mathrm{VPDB})}$

774 values for individuals from across Canada.

775

776 Figure 6. The relationships between $\delta^{18} \mathrm{O}_{\mathrm{c}(\mathrm{VSMOW})}$ and $\delta^{18} \mathrm{O}_{\mathrm{dw}}$ values are shown for individuals

777 who had resided in Canada during tissue formation $(n=41)$. Colours indicate the MV or non-MV

778 residence, and shapes indicate the type of drinking water sampled for its $\delta^{18} \mathrm{O}_{\mathrm{dw}}$ value. The

Updated: March 17, 2021 
779 different line types show the regression line between $\delta^{18} \mathrm{O}_{\mathrm{c}}$ and $\delta^{18} \mathrm{O}_{\text {tap }}$ values for $\mathrm{Eq}(2): \delta$

$780{ }^{18} \mathrm{O}_{\mathrm{c}(\mathrm{VSMOW})}=0.11( \pm 0.09) \times \delta^{18} \mathrm{O}_{\mathrm{tap}(\mathrm{VSMOW})}+23.29( \pm 0.98) ;\left[\mathrm{df}=32 ; \bar{R}^{2}=0.01\right], \delta^{18} \mathrm{O}_{\mathrm{dw}}$ values

781 including both tap and surface water values for $\mathrm{Eq}(3): \delta^{18} \mathrm{O}_{\mathrm{c}(\mathrm{VSMOW})}=0.16( \pm 0.08) \times \delta$

$782{ }^{18} \mathrm{O}_{\mathrm{dw} \_} 1$ (VSMOW $)+23.77( \pm 0.82) ;\left[\mathrm{df}=35 ; \bar{R}^{2}=0.09\right]$ and $\delta^{18} \mathrm{O}_{\mathrm{dw}}$ values for all samples for Eq

783 (4): $\delta^{18} \mathrm{O}_{\mathrm{c}(\text { VSMOW })}=0.15( \pm 0.07) \times \delta^{18} \mathrm{O}_{\mathrm{dw} \_} 2$ (VSMOW) $)+23.65( \pm 0.78) ; \quad\left[\mathrm{df}=37 ; \bar{R}^{2}=0.08\right]$.

784 Generally, positive but weak correlations were observed between the two values.

786 Figure 7. A boxplot of $\delta^{18} \mathrm{O}_{\mathrm{c}}$ values for the globally aggregated data represented by country

787 ( $\mathrm{n}=75)$. The boxes represent $25^{\text {th }}$ and $75^{\text {th }}$ percentiles, and whiskers represent the maximum and

788 minimum observations. When outliers are present, the whiskers extend to 1.5 times the

789 interquartile range. The middle line denotes the median or $50^{\text {th }}$ percentile.

790

791 Figure 8: A plot of latitude vs $\delta^{18} \mathrm{O}_{\mathrm{c}(\mathrm{VSMOW})}$ of all data ( $\left.\mathrm{n}=75\right)$. A general latitidunal trend can be 792 observed with $\delta^{18} \mathrm{O}_{\mathrm{c}}$ values increasing decreasing latitude.

794 Figure 9. The relationships between $\delta^{18} \mathrm{O}_{\mathrm{c}(\mathrm{VSMOw})}$ and $\delta^{18} \mathrm{O}_{\mathrm{dw}}$ values are shown for all sampled 795 individuals $(\mathrm{n}=75)$. Colours indicate the country of residence, and shapes indicate the type of 796 drinking water sampled for its $\delta^{18} \mathrm{O}_{\mathrm{dw}}$ value. The different line types show the regression line 797 between $\delta^{18} \mathrm{O}_{\mathrm{c}}$ and $\delta^{18} \mathrm{O}_{\text {tap }}$ values for $\mathrm{Eq}(5): \delta^{18} \mathrm{O}_{\mathrm{c}(\mathrm{VSMOW})}=0.11( \pm 0.09) \times \delta^{18} \mathrm{O}_{\text {tap(VSMOW })}+$ $79823.29( \pm 0.98) ;\left[\mathrm{df}=32 ; \bar{R}^{2}=0.01\right], \delta^{18} \mathrm{O}_{\mathrm{dw}}$ values including both tap and surface water values for

$799 \mathrm{Eq}(6): \delta^{18} \mathrm{O}_{\mathrm{c}(\mathrm{VSMOW})}=0.16( \pm 0.08) \times \delta^{18} \mathrm{O}_{\mathrm{dw} \_} 1(\mathrm{VSMOW})+23.77( \pm 0.82) ;\left[\mathrm{df}=35 ; \bar{R}^{2}=0.09\right]$

800 and $\delta^{18} \mathrm{O}_{\mathrm{dw}}$ values for all samples for Eq (7): $\delta^{18} \mathrm{O}_{\mathrm{c}(\mathrm{VSMOW})}=0.15( \pm 0.07) \times \delta^{18} \mathrm{O}_{\mathrm{dw}} 2$ (vSMOw) + Updated: March 17, 2021 
$80123.65( \pm 0.78) ;\left[\mathrm{df}=37 ; \bar{R}^{2}=0.08\right]$. The solid grey line represents the regression line between

$802 \delta^{18} \mathrm{O}_{\mathrm{c}}$ and $\delta^{18}$ OoIPC values; $\mathrm{Eq}(8): \delta^{18} \mathrm{O}_{\mathrm{c}(\mathrm{VSMOW})}=0.43( \pm 0.05) \times \delta^{18}$ OoIPC(VSMOW $)+26.92$

$803( \pm 0.46) ;\left[\mathrm{df}=73, \bar{R}^{2}=0.51\right]$. Generally, positive but weak correlations were observed between the 804 two values.

806 Figure 10. Range of $\delta^{18} \mathrm{O}_{\mathrm{c}}$ values as predicted by an equation or a combination of equations from 807 the actual MV $\delta^{18} \mathrm{O}_{\text {tap }}$ range $(-11.7$ to $-9.3 \%$ ). Equations include all existing predictive models 808 and equations from the current study (U1, U2, U3, U4, U5, U6, U7, UOIPC). Predicted ranges 809 were generally more positive than the actual range for MV. 15 of the 44 predicted ranges fell 810 outside the actual MV range. The best performing predictive model was Dotsika ${ }^{40}$ (Do), which 811 accurately identified $91.7 \%$ of the MV individuals residing in MV during tissue formation.

813 Figure 11. $\delta^{18} \mathrm{O}_{\mathrm{dw}}$ values were calculated from all $\delta^{18} \mathrm{O}_{\mathrm{c}(\text { Vsmow) }}$ values $(\mathrm{n}=75)$ using an existing 814 predictive model or a set of models. For those equations giving the relationship between $\mathrm{O}_{\mathrm{p}}$ to

$815 \mathrm{O}_{\mathrm{dw}}$, the values were first converted to $\mathrm{O}_{\mathrm{p}}$ from $\mathrm{O}_{\mathrm{c}}$ using an equation that shows the relationship 816 between carbonate and phosphate oxygen. Shapes denote carbonate to phosphate oxygen

817 conversions. The OIPC line represents the relationship between $\delta^{18} \mathrm{O}_{\mathrm{c}(\mathrm{VMOSW})}$ and $\delta^{18} \mathrm{OoIPC}$ 818 values.

820 Figure 12. Differences between predicted and observed $\delta^{18} \mathrm{O}_{\mathrm{dw}}$ values for (a) tap water and (b) 821 OIPC for all samples from the current study $(n=75) . \delta^{18} \mathrm{O}_{\mathrm{dw}}$ values were predicted from $\delta^{18} \mathrm{O}_{\mathrm{c}}$ 822 values with existing predictive models or a combination of models. $\delta^{18} \mathrm{O}_{\mathrm{c}}$ values were initially Updated: March 17, 2021 
823 converted to $\delta^{18} \mathrm{O}_{\mathrm{p}}$ values before applying the equations that represent the relationship between

$824 \delta^{18} \mathrm{O}_{\mathrm{p}}$ and $\delta^{18} \mathrm{O}_{\mathrm{dw}}$ values. Shapes denote carbonate to phosphate oxygen conversions, and colors

825 represent the enamel to drinking water conversion equations.

826

827 Figure 13. A direct comparison of the mean standard deviation (MSD) between predicted and

828 observed $\delta^{18} \mathrm{O}_{\mathrm{dw}}$ values for (a) tap water and (b) OIPC. $\delta^{18} \mathrm{O}_{\mathrm{dw}}$ values were predicted from $\delta^{18} \mathrm{O}_{\mathrm{c}}$

829 values of all samples $(n=75)$ from the current study with existing predictive models or a

830 combination of models. MSD components are lack of correlation (LC), non-unity slope (NU)

831 and squared bias (SB). Low MSD indicates greater similarity between modelled and measured

832 values.

833

\section{Tables}

835 Table 1. Summary of molar formation ${ }^{74}$.

\begin{tabular}{lllll}
\hline & Tooth & Formation of tissue & Crown completion & Root completion \\
\hline Permanent maxillary teeth & First & Birth & $2.5-3$ years & $9-10$ years \\
& Second & $2.5-3$ years & $7-8$ years & $14-16$ years \\
& Third & $7-9$ years & $12-16$ years & $18-25$ years \\
Permanent mandibular teeth & First & Birth & $2.5-3$ years & $9-10$ years \\
& Second & $2.5-3$ years & $7-8$ years & $14-15$ years \\
& Third & $8-10$ years & $12-16$ years & $18-25$ years \\
\hline
\end{tabular}

836 Table 2. Existing conversion equations.

\begin{tabular}{lllll}
\hline Conversion & Study & Equation & $\mathrm{n}$ & $\mathrm{r}^{2}$ \\
\hline VPDB to VSMOW & Coplen $(1988)$ & $\delta^{18} \mathrm{O}_{\mathrm{x} / \text { VSMOw }}=1.03091 \delta^{18} \mathrm{O}_{\mathrm{x} / \mathrm{VPDB}}+30.91$ & \\
& & $\delta^{18} \mathrm{O}_{\mathrm{x} / \mathrm{VPDB}}=0.97001 \delta^{18} \mathrm{O}_{\mathrm{x} / \mathrm{VSMOW}-29.99}$ & \\
\hline$\delta^{18} \mathrm{O}_{\mathrm{p}}$ to $\delta{ }^{18} \mathrm{O}_{\mathrm{c}}$ & Iacumin et al. ${ }^{19}$ & $\delta^{18} \mathrm{O}_{\mathrm{p}(\mathrm{SMOW})}=0.98 \delta^{18} \mathrm{O}_{\mathrm{c}(\mathrm{SMOW})}-8.5$ & 31 & 0.98 \\
& Bryant et al. ${ }^{18}$ & $\delta^{18} \mathrm{O}_{\mathrm{c}}( \pm 1.3)=1.02( \pm 0.04) \delta^{18} \mathrm{O}_{\mathrm{p}}+8.3( \pm 0.7)$ & 42 & 0.99 \\
& Wright et al. ${ }^{21}$ & $\delta^{18} \mathrm{O}_{\mathrm{p}(\mathrm{SMOW})}=0.899 \delta{ }^{18} \mathrm{O}_{\mathrm{c}(\mathrm{PDB})}+21.397$ & &
\end{tabular}

Updated: March 17, 2021 


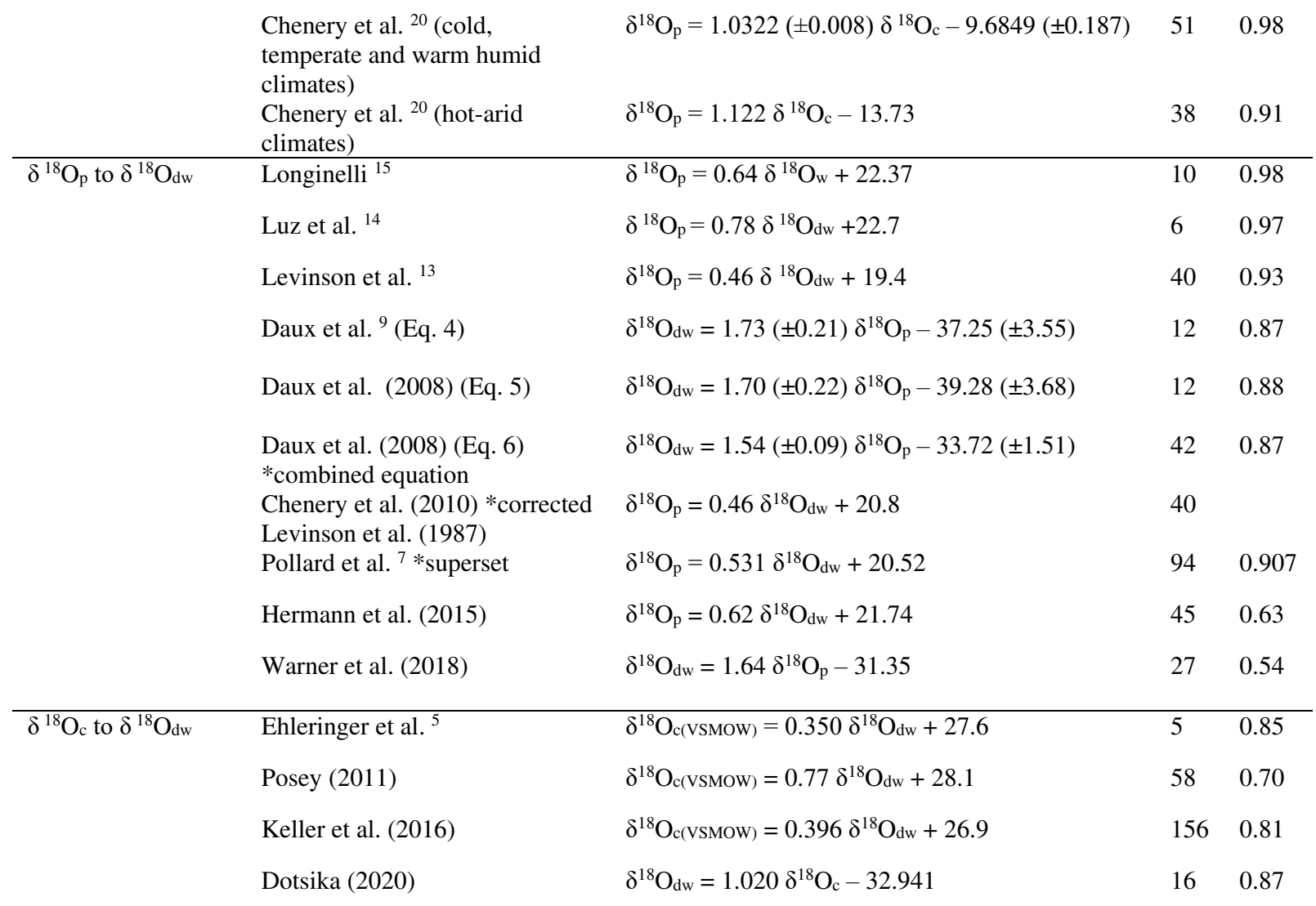

837 Table 3. Fractional contributions of water sources to MV municipal tap water supply.

\begin{tabular}{|c|c|c|c|c|c|}
\hline \multirow[b]{2}{*}{ Mean annual $\delta{ }^{18} \mathrm{O}_{\text {tap }}$} & Capilano & Seymour & Coquitlam & Well & \multirow[b]{3}{*}{$\delta^{18} \mathrm{O}_{\text {(mean) }}$} \\
\hline & -11.6 & -11.6 & -11.1 & -11.1 & \\
\hline Municipality & \multicolumn{4}{|c|}{ Fractional contributions $(f)$} & \\
\hline Burnaby & 0.045 & 0.955 & 0 & 0 & -11.7 \\
\hline Coquitlam & 0 & 0 & 1.00 & 0 & -11.1 \\
\hline Langley and Township of Langley & 0 & 0 & 0.47 & 0.53 & -11.1 \\
\hline New Westminster & 0 & 0.20 & 0.80 & 0 & -11.2 \\
\hline North Vancouver & 0.50 & 0.50 & 0.00 & 0.00 & -11.7 \\
\hline Richmond & 0.495 & 0.495 & 0.00 & 0.00 & -11.6 \\
\hline Surrey & 0.00 & 0.41 & 0.59 & 0.00 & -11.3 \\
\hline Vancouver & 0.62 & 0.38 & 0.00 & 0.00 & -11.7 \\
\hline
\end{tabular}

838 Table 4. Summary of studies on predictive models.

\begin{tabular}{llllll}
\hline Study & Time period & Sampled Material & $\begin{array}{l}\text { Geographical } \\
\text { scale }\end{array}$ & $\begin{array}{l}\text { Definition of } \\
\text { drinking water }\end{array}$ & Oxygen analysis \\
\hline Longinelli (1984) & $\begin{array}{l}\text { End of 19th } \\
\text { century }\end{array}$ & Human bone & Global & Meteoric water & Phosphate (BiPO4)
\end{tabular}

Updated: March 17, 2021 


\begin{tabular}{|c|c|c|c|c|c|}
\hline Luz et al. (1984) & unspecified & Human tooth & Global & $\begin{array}{l}\text { Estimated } \\
\text { precipitation and } \\
\text { tap water }\end{array}$ & Phosphate $\left(\mathrm{BiPO}_{4}\right)$ \\
\hline Levinson et al. (1987) & Modern & Human tooth & Global & Unspecified & Phosphate $\left(\mathrm{BiPO}_{4}\right)$ \\
\hline Daux et al. (2008) Eq. 4 & $\begin{array}{l}\text { Modern and } \\
\text { historical } \\
\text { (Greenland) }\end{array}$ & $\begin{array}{l}\text { Human } 2^{\text {nd }} \text { and } 3^{\text {rd }} \\
\text { molars }\end{array}$ & Global & $\begin{array}{l}\text { Tap water (OPIC } \\
\text { for Disko Bay) }\end{array}$ & Phosphate $\left(\mathrm{Ag}_{3} \mathrm{PO}_{4}\right)$ \\
\hline Daux et al. (2008) Eq. 5 & $\begin{array}{l}\text { Modern and } \\
\text { historical } \\
\text { (Greenland) }\end{array}$ & $\begin{array}{l}\text { Human } 2^{\text {nd }} \text { and } 3^{\text {rd }} \\
\text { molars }\end{array}$ & Global & $\begin{array}{l}\text { OIPC } \\
\text { precipitation } \\
\text { estimate }\end{array}$ & Phosphate $\left(\mathrm{Ag}_{3} \mathrm{PO}_{4}\right)$ \\
\hline Ehleringer et al. ${ }^{5}$ & Modern & Human tooth & Country (U.S.) & Tap water & Carbonate \\
\hline Posey (2011) & Modern & $\begin{array}{l}\text { Human tooth } \\
\text { (incisors, canines, } \\
\text { premolars, } \\
\text { molars) }\end{array}$ & $\begin{array}{l}\text { Region (Middle } \\
\text { East) }\end{array}$ & Tap water & Carbonate \\
\hline Hermann et al. (2015) & Modern & Human tooth & Country (U.S.) & Meteoric water & Phosphate $\left(\mathrm{Ag}_{3} \mathrm{PO}_{4}\right)$ \\
\hline Keller et al. (2016) & Modern & Human $3^{\text {rd }}$ molars & Country (U.S.) & River water & Carbonate \\
\hline Warner et al. (2018) & Modern & Human $3^{\text {rd }}$ molars & $\begin{array}{l}\text { State } \\
\text { (Mississippi, } \\
\text { U.S.) }\end{array}$ & Tap water & Carbonate \\
\hline Dotsika (2020) & Modern & Human $2^{\text {nd }}$ molars & $\begin{array}{l}\text { Country } \\
\text { (Greece) }\end{array}$ & Spring water & Carbonate \\
\hline
\end{tabular}




\section{Figures}

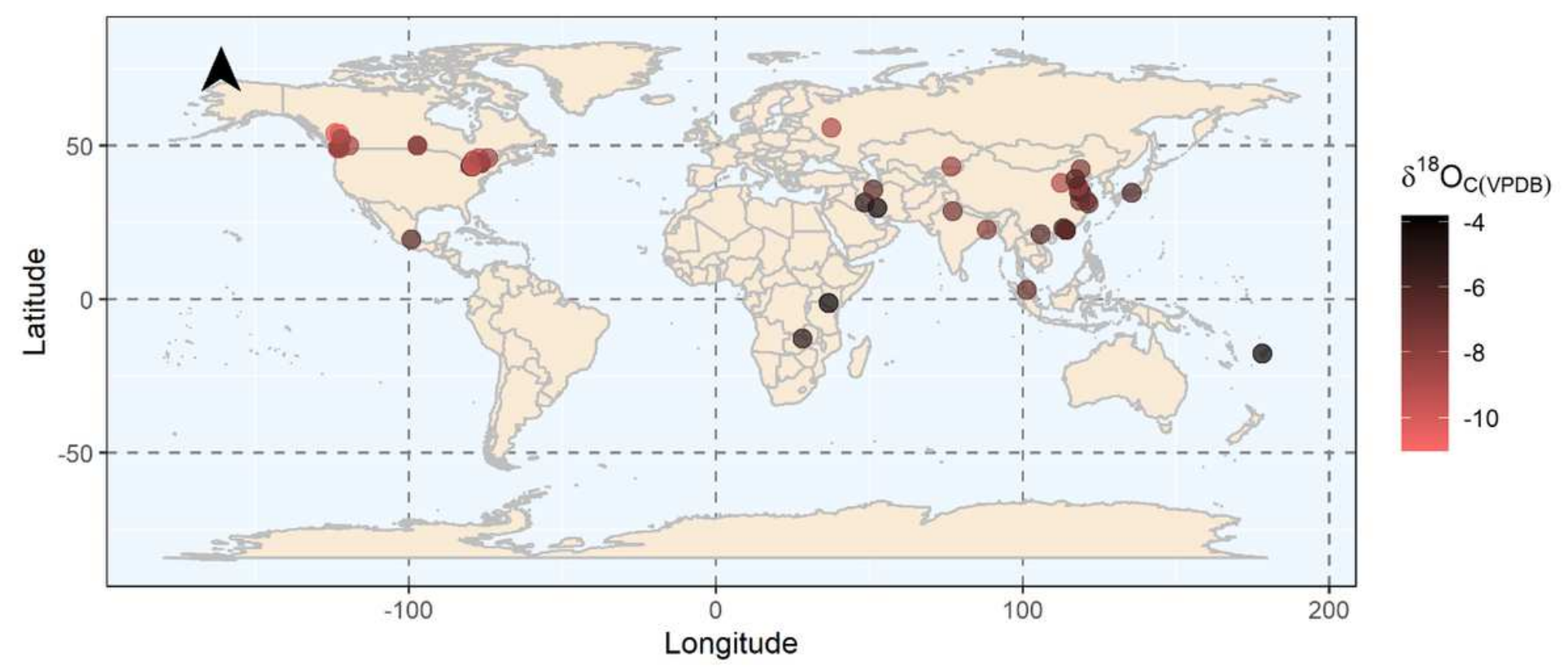

Figure 1

Locations of residence during tissue formation with the corresponding $8180 \mathrm{C}(\mathrm{VPDB})$ values for all collected samples. Note: The designations employed and the presentation of the material on this map do not imply the expression of any opinion whatsoever on the part of Research Square concerning the legal status of any country, territory, city or area or of its authorities, or concerning the delimitation of its frontiers or boundaries. This map has been provided by the authors. 


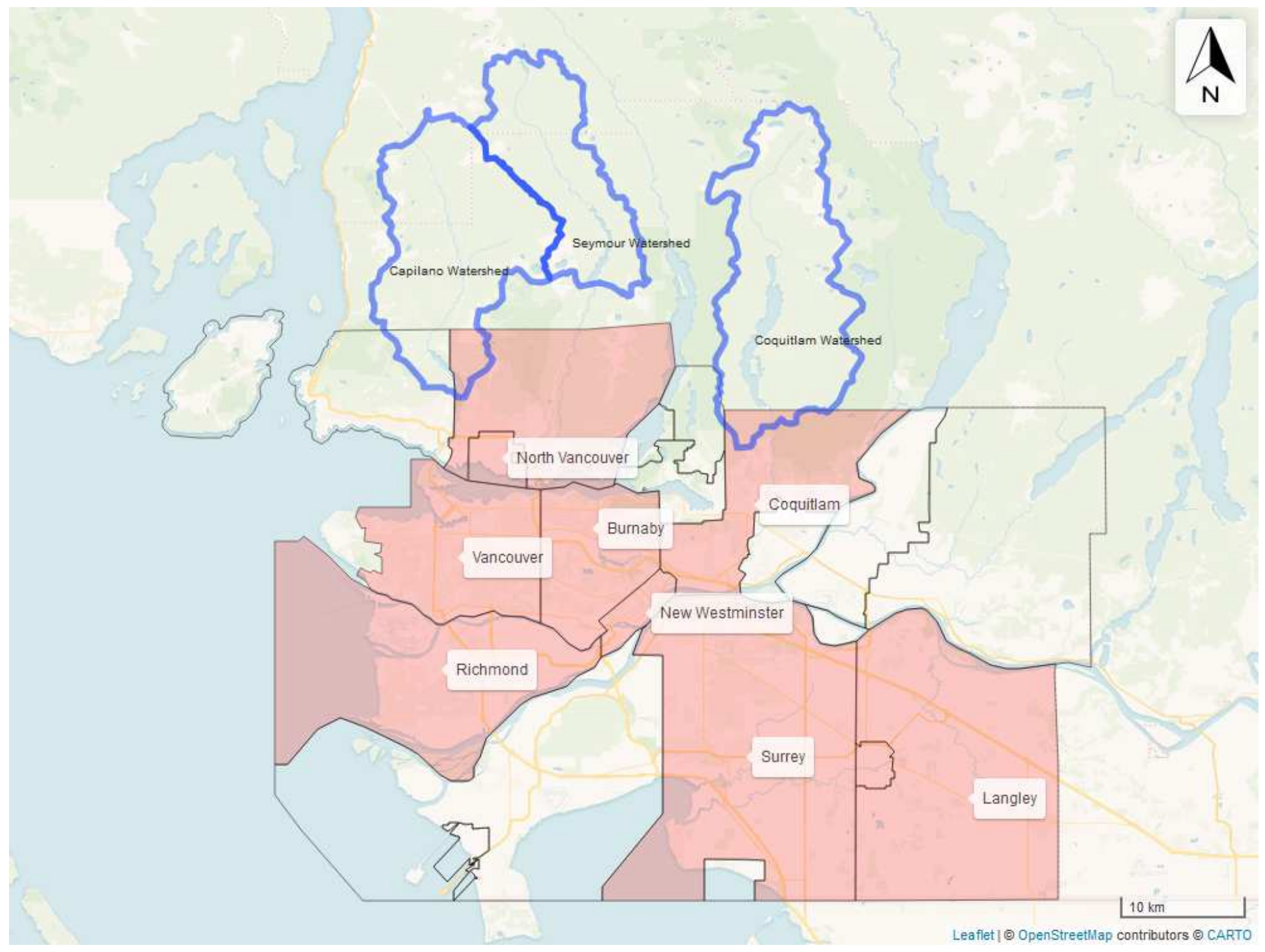

\section{Figure 2}

Map of MV with the shaded areas representing sampled municipalities. Note: The designations employed and the presentation of the material on this map do not imply the expression of any opinion whatsoever on the part of Research Square concerning the legal status of any country, territory, city or area or of its authorities, or concerning the delimitation of its frontiers or boundaries. This map has been provided by the authors. 

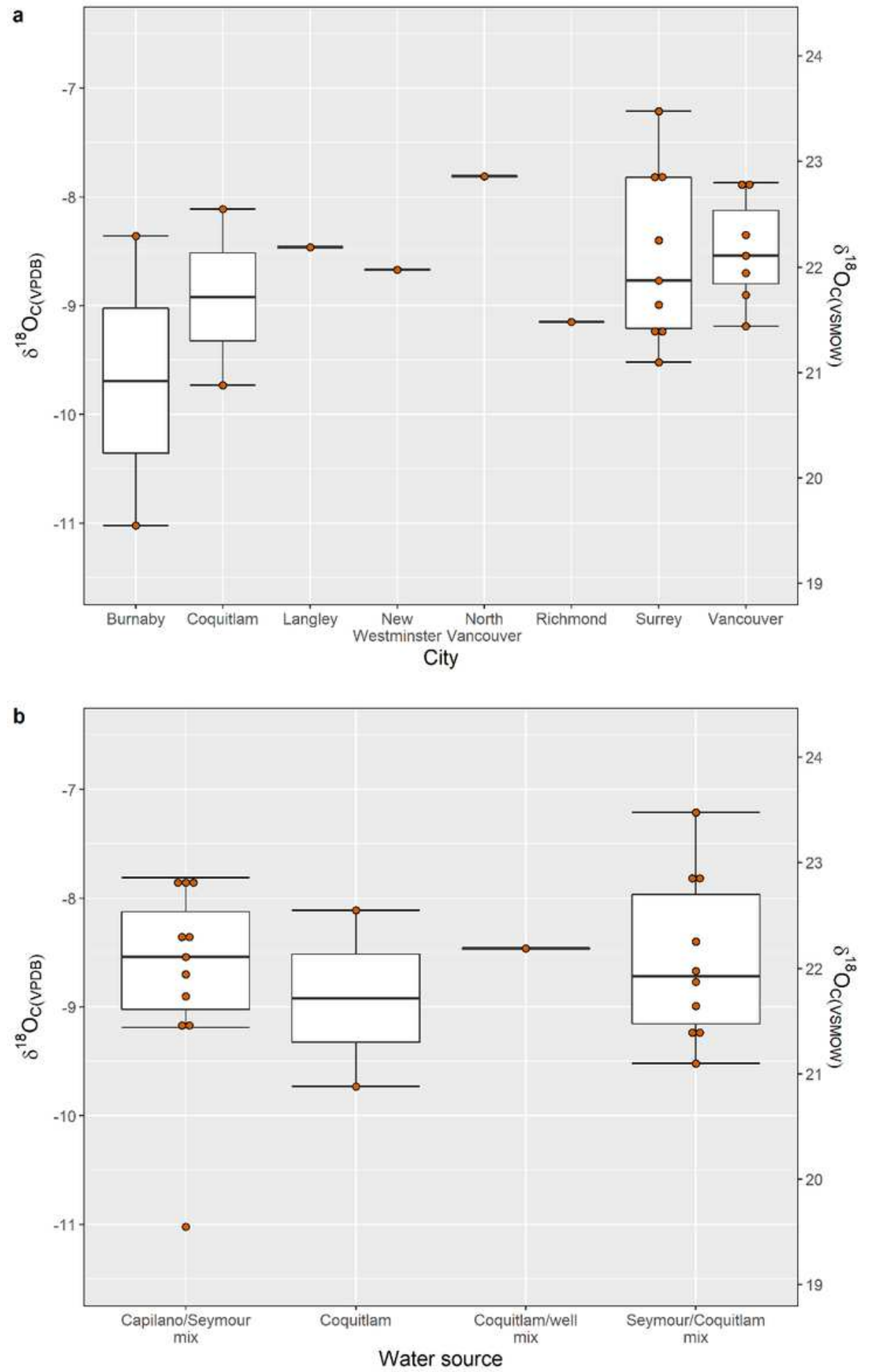

\section{Figure 3}

Boxplots of MV $\delta 180 C$ values as represented by a) city and b) tap water source. The boxes represent 25th and 75th percentiles, and whiskers represent the maximum and minimum observations. When outliers are present, the whiskers extend to 1.5 times the interquartile range. The middle line denotes the median or 50 th percentile. One-way ANOVA tests showed no statistically significant inter-city differences 
between mean $\delta 180 c$ values for $\mathrm{MV}[F(7,16)=0.717, \mathrm{p}=6.59]$, nor for mean $\mathrm{MV} \delta 180 c(\mathrm{VPDB})$ values for data disaggregated by tap water source $[F(4,19)=1.013, p=0.426]$.

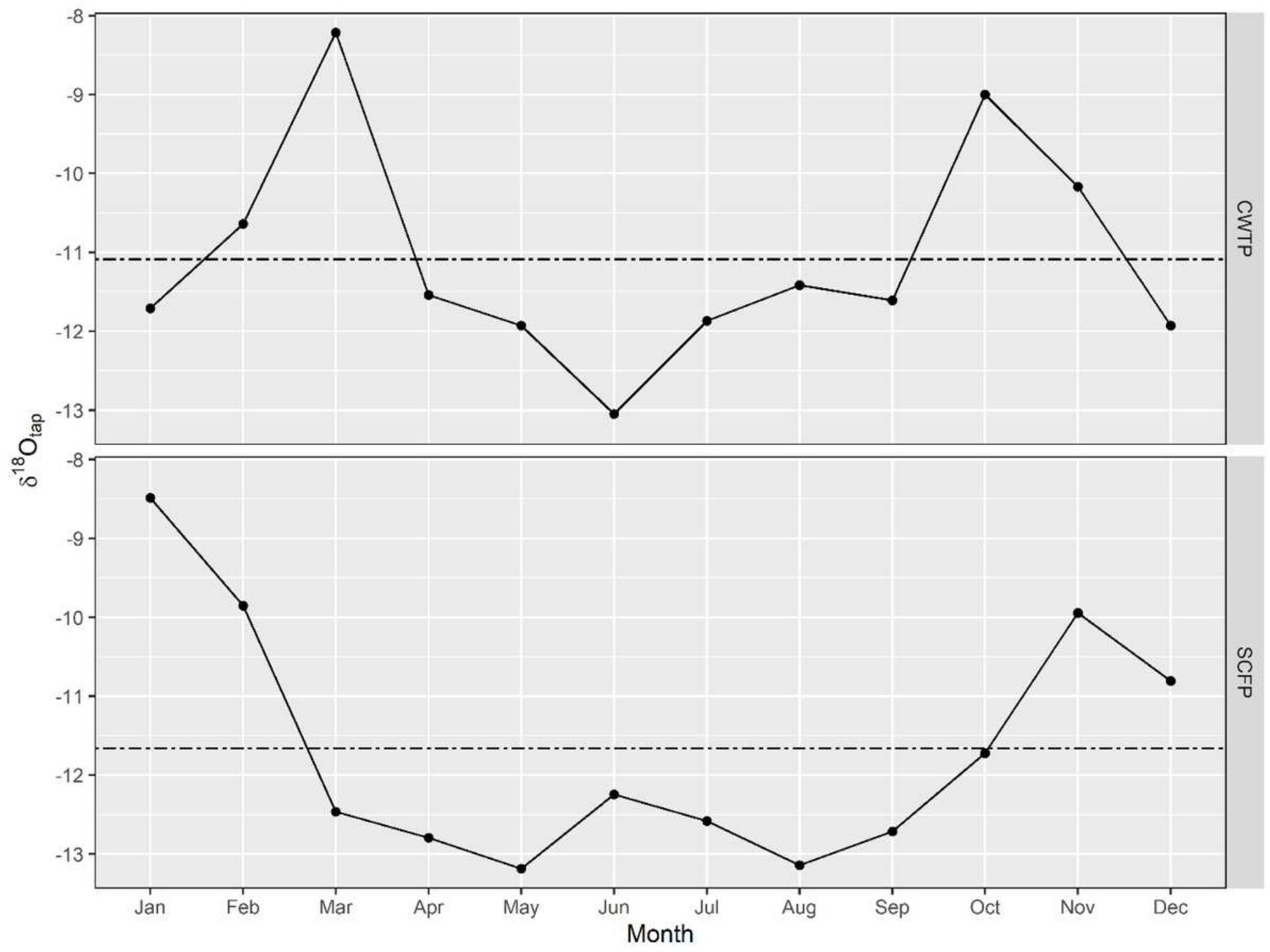

Figure 4

Monthly MV tap water $\delta 180$ data for samples taken between June 2017 to May 2018 at Coquitlam Water Treatment Plant (CWTP) and Seymour-Capilano Filtration Plant (SCFP). Mean annual MV tap water $\delta 180$ values were $-11.1 \%$ and $-11.7 \%$ at CWTP and SCFP, respectively. 


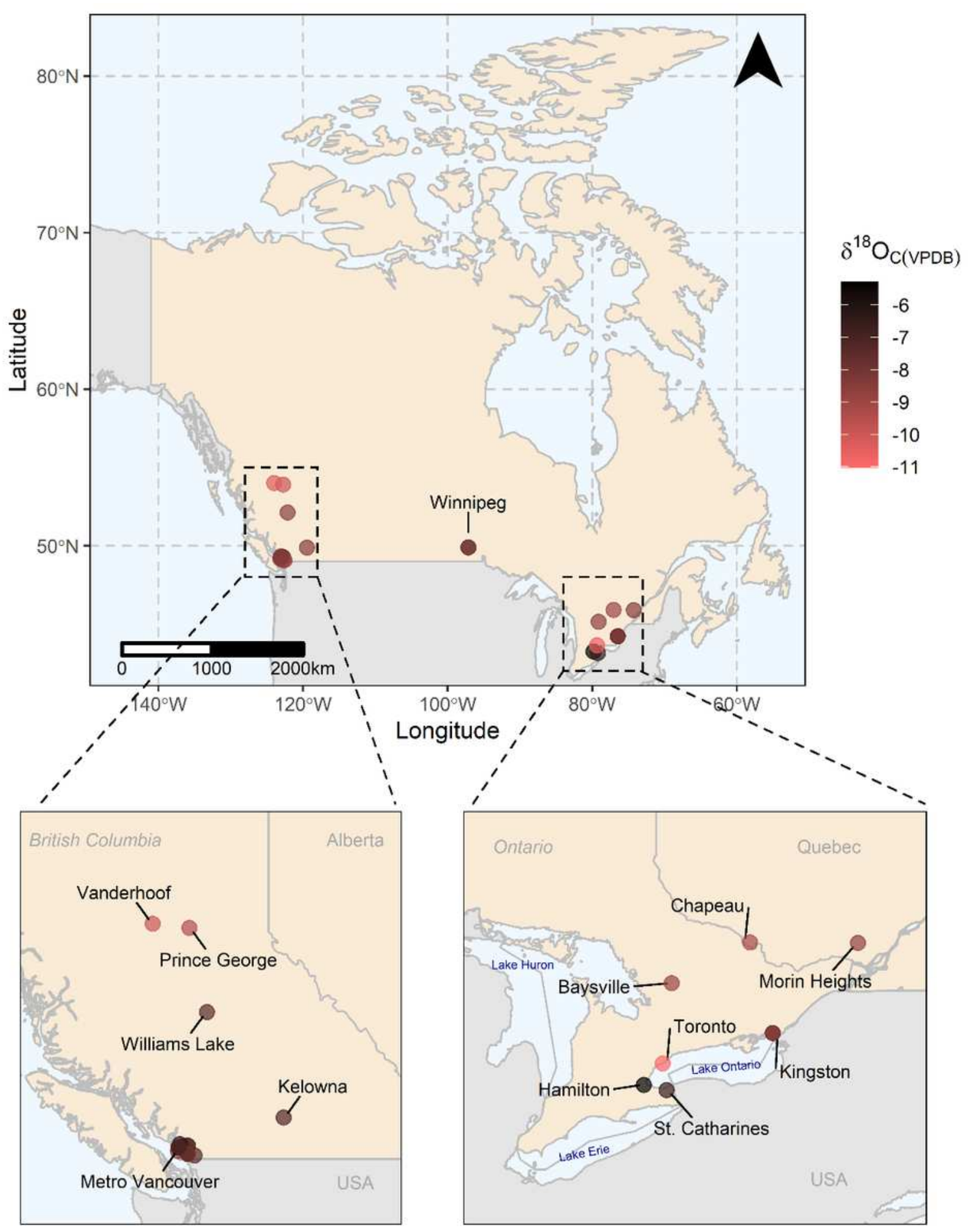

\section{Figure 5}

Location of residence during tissue formation with the corresponding $8180 C(V P D B)$ values for individuals from across Canada. Note: The designations employed and the presentation of the material on this map do not imply the expression of any opinion whatsoever on the part of Research Square concerning the legal status of any country, territory, city or area or of its authorities, or concerning the delimitation of its frontiers or boundaries. This map has been provided by the authors. 


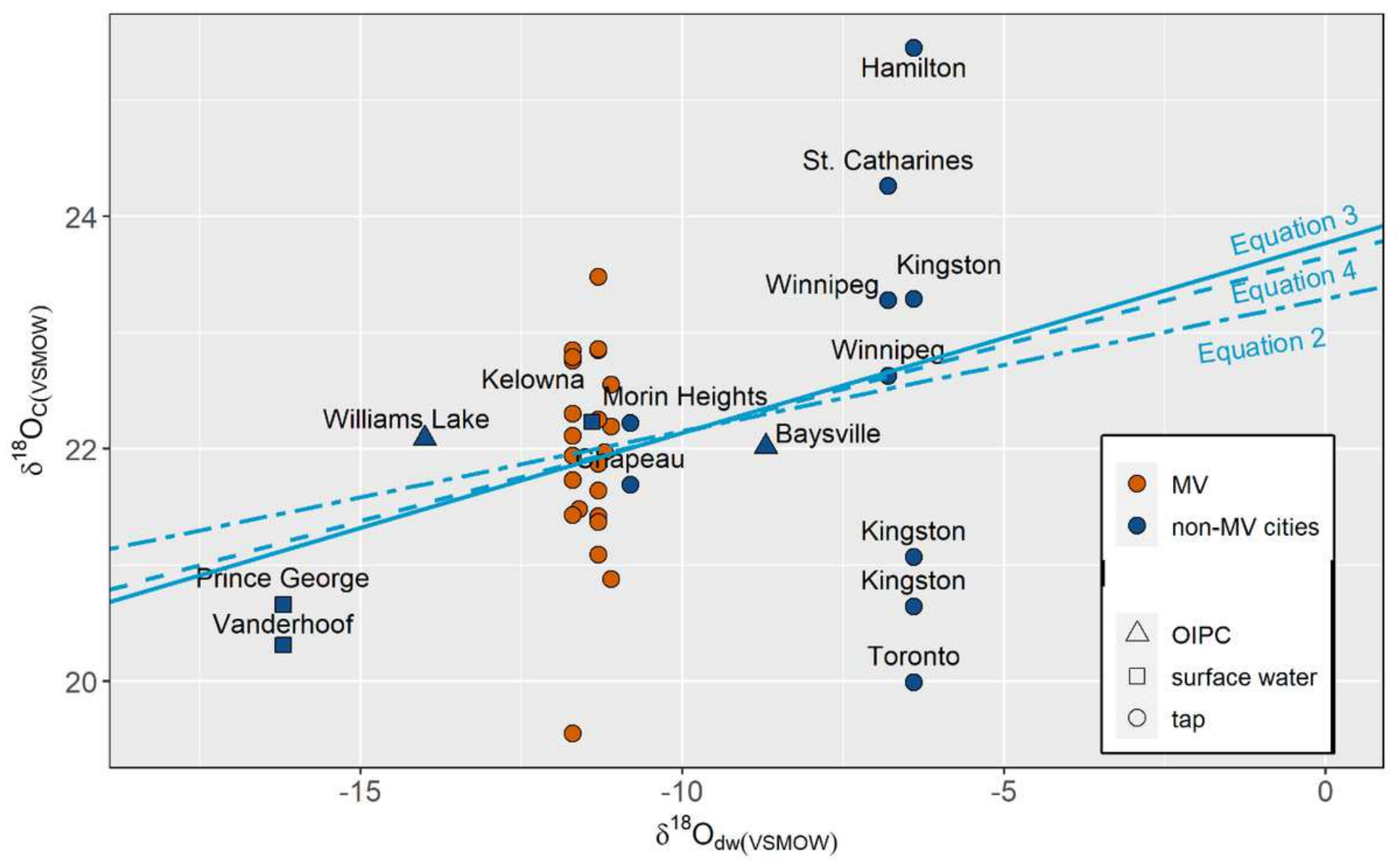

Figure 6

The relationships between $\delta 180 c($ VSMOW) and $\delta 180 \mathrm{dw}$ values are shown for individuals who had resided in Canada during tissue formation $(n=41)$. Colours indicate the MV or non-MV residence, and shapes indicate the type of drinking water sampled for its $\delta 180 \mathrm{dw}$ value. The different line types show the regression line between $\delta 180 \mathrm{c}$ and $\delta 180$ tap values for $\mathrm{Eq}(2)$ : $\delta 180 \mathrm{c}(\mathrm{VSMOW})=0.11( \pm 0.09) \times \delta$ $180 \operatorname{tap}(\mathrm{VSMOW})+23.29( \pm 0.98) ;[\mathrm{df}=32 ; \mathrm{R} \otimes 2=0.01]$, $8180 \mathrm{dw}$ values including both tap and surface water values for Eq (3): $\delta 180 c(V S M O W)=0.16( \pm 0.08) \times \delta$ 180dw_1 $($ VSMOW $)+23.77( \pm 0.82) ;[\mathrm{df}=35$; $R \llbracket 2=0.09]$ and $\delta 180 \mathrm{dw}$ values for all samples for Eq (4): $\delta 180 c($ VSMOW $)=0.15( \pm 0.07) \times \delta$ 180dw_2(VSMOW $)+23.65( \pm 0.78) ;[\mathrm{df}=37 ; \mathrm{R} \otimes 2=0.08]$. Generally, positive but weak correlations were observed between the two values. 


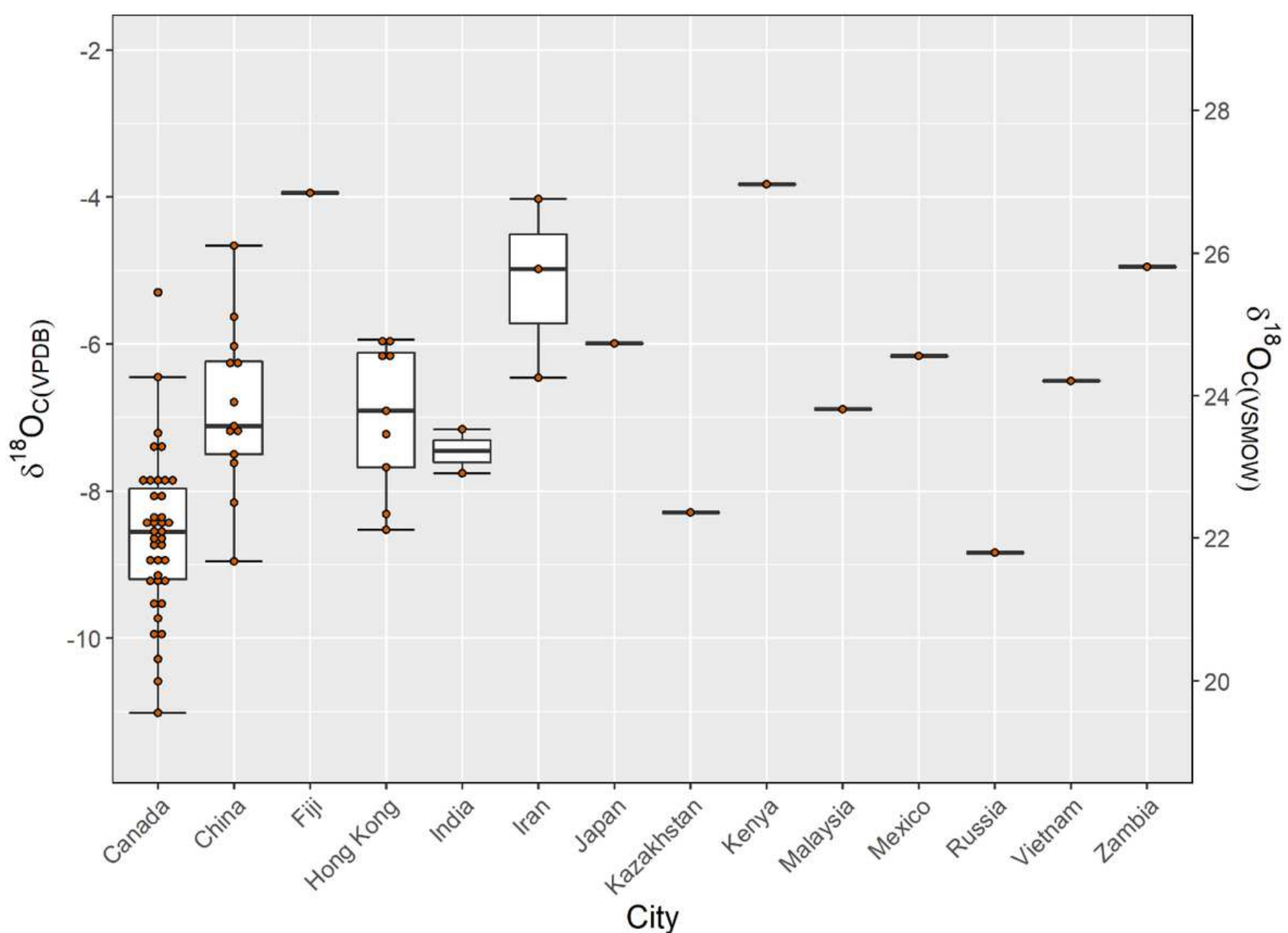

Figure 7

A boxplot of $\delta 180 \mathrm{c}$ values for the globally aggregated data represented by country $(n=75)$. The boxes represent 25th and 75th percentiles, and whiskers represent the maximum and minimum observations. When outliers are present, the whiskers extend to 1.5 times the interquartile range. The middle line denotes the median or 50th percentile. 


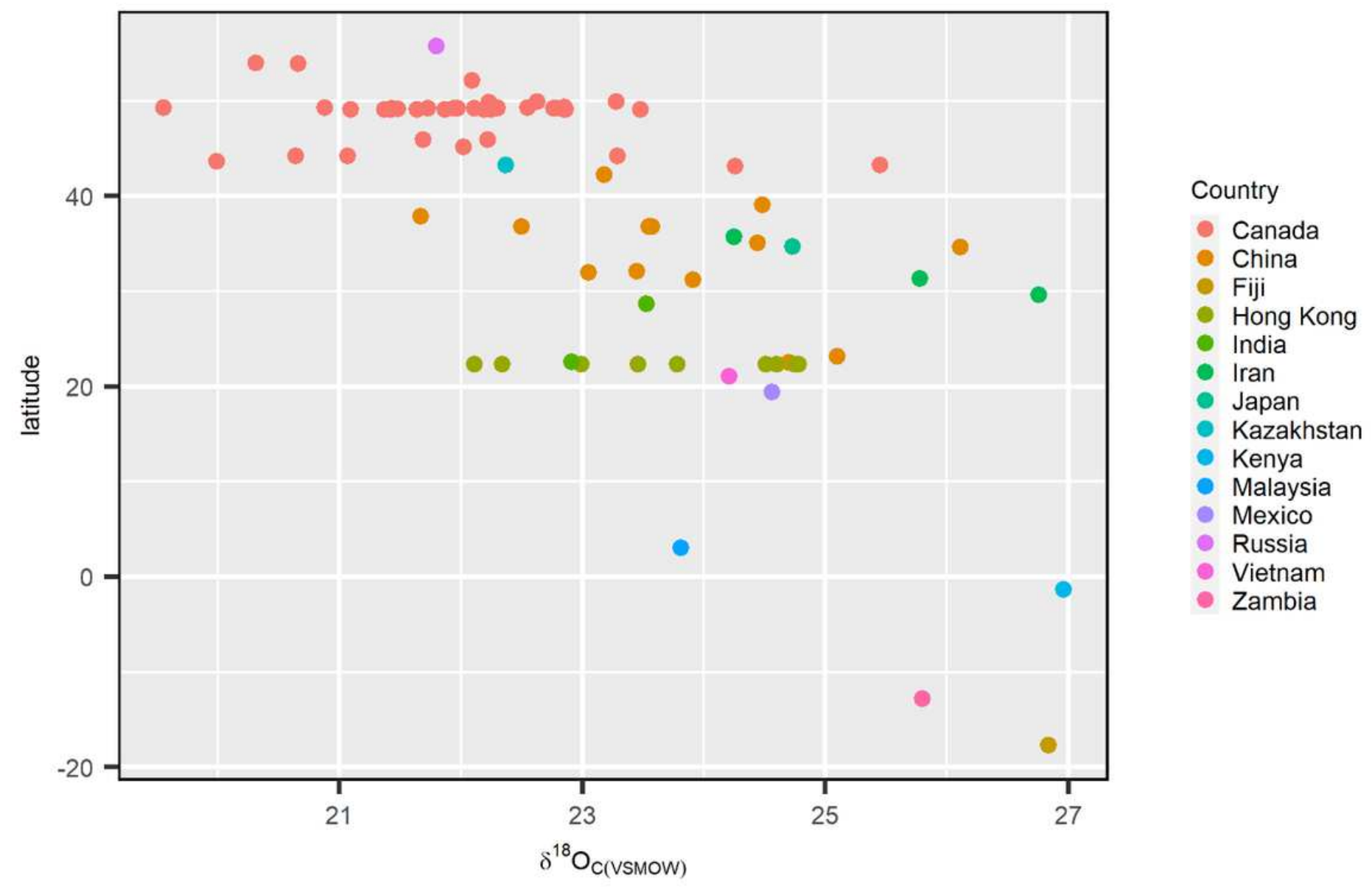

Figure 8

A plot of latitude vs $\delta 180 c(V S M O W)$ of all data $(n=75)$. A general latitidunal trend can be observed with $\delta 180 \mathrm{c}$ values increasing decreasing latitude. 


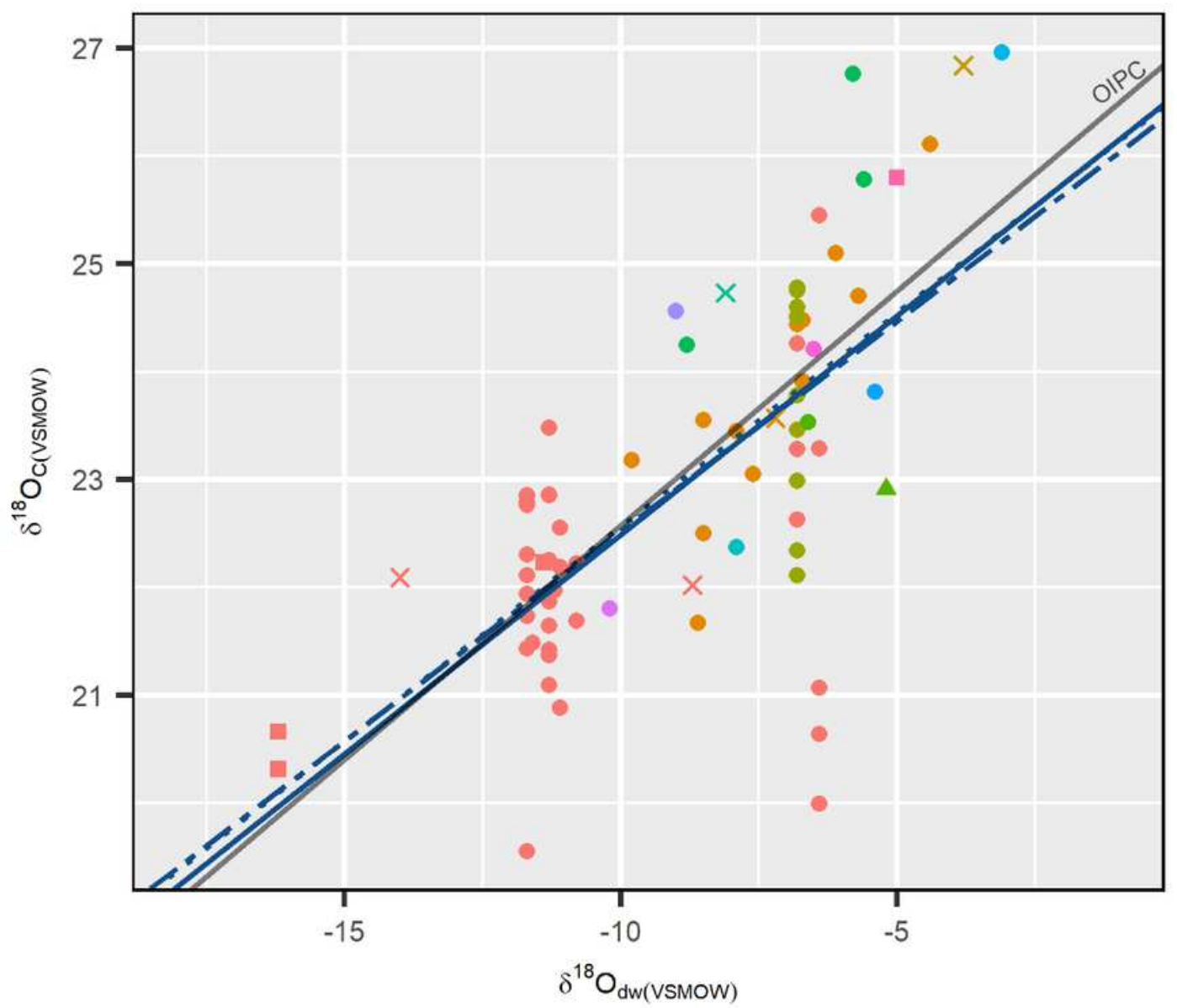

Equation 5

Equation 6

- Equation 7

\section{Country}

- Canada

- China

- Fiji

- Hong Kong

- India

- Iran

- Japan

- Kazakhstan

- Kenya

- Malaysia

- Mexico

- Russia

- Vietnam

- Zambia

\section{Type of drinking water}

$\Delta$ groundwater

$x$ OIPC

- surface water

- tap

\section{Figure 9}

The relationships between $\delta 180 c($ VSMOW) and $\delta 180 \mathrm{dw}$ values are shown for all sampled individuals $(n=75)$. Colours indicate the country of residence, and shapes indicate the type of drinking water sampled for its $\delta 180 \mathrm{dw}$ value. The different line types show the regression line between $8180 \mathrm{c}$ and $8180 \mathrm{tap}$ values for $\mathrm{Eq}(5)$ : $\delta 180 \mathrm{c}(\mathrm{VSMOW})=0.11( \pm 0.09) \times \delta 180 \operatorname{tap}(\mathrm{VSMOW})+23.29( \pm 0.98) ;[\mathrm{df}=32 ; \mathrm{R} \otimes 2=$ $0.01], \delta 180 \mathrm{dw}$ values including both tap and surface water values for Eq (6): $\delta 180 \mathrm{c}(\mathrm{VSMOW})=0.16$ $( \pm 0.08) \times \delta 180 d_{w} \_1(V S M O W)+23.77( \pm 0.82) ;[d f=35 ; R \otimes 2=0.09]$ and $\delta 180 d w$ values for all samples for Eq (7): $\delta 180 c(V S M O W)=0.15( \pm 0.07) \times \delta 180 d w \_2(V S M O W)+23.65( \pm 0.78) ;[d f=37 ; R \otimes 2=0.08]$. The solid grey line represents the regression line between $\delta 180 \mathrm{c}$ and $81800 \mathrm{IPC}$ values; Eq (8): $\delta 180 c($ VSMOW $)=0.43( \pm 0.05) \times \delta 1800 I P C(V S M O W)+26.92( \pm 0.46) ;[d f=73, R \otimes 2=0.51]$. Generally, positive but weak correlations were observed between the two values. 


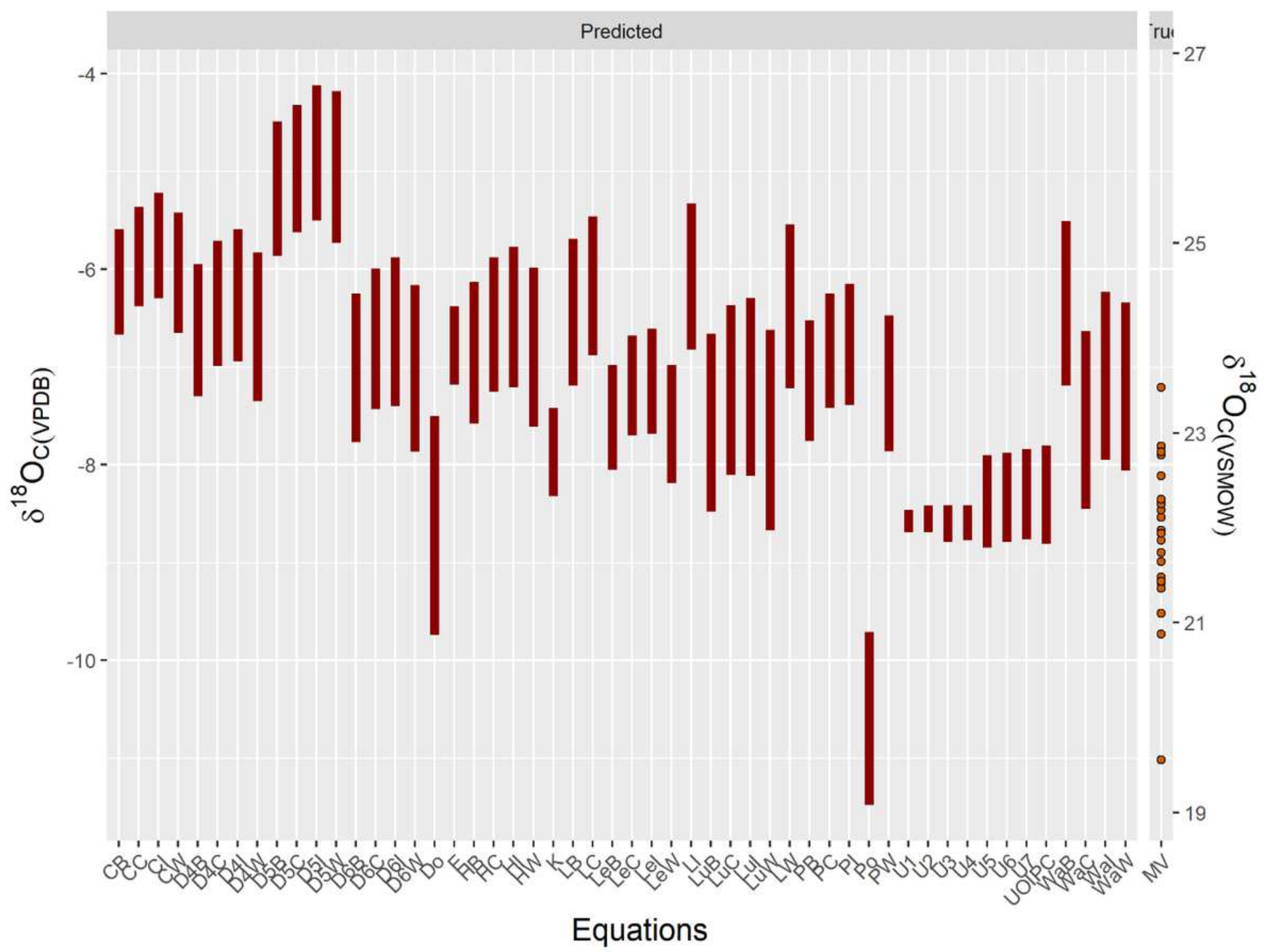

Figure 10

Range of $8180 \mathrm{c}$ values as predicted by an equation or a combination of equations from the actual MV 6180tap range ( -11.7 to $-9.3 \%$ ). Equations include all existing predictive models and equations from the current study (U1, U2, U3, U4, U5, U6, U7, UOIPC). Predicted ranges were generally more positive than the actual range for MV. 15 of the 44 predicted ranges fell outside the actual MV range. The best performing predictive model was Dotsika 40 (Do), which accurately identified $91.7 \%$ of the MV individuals residing in MV during tissue formation. 


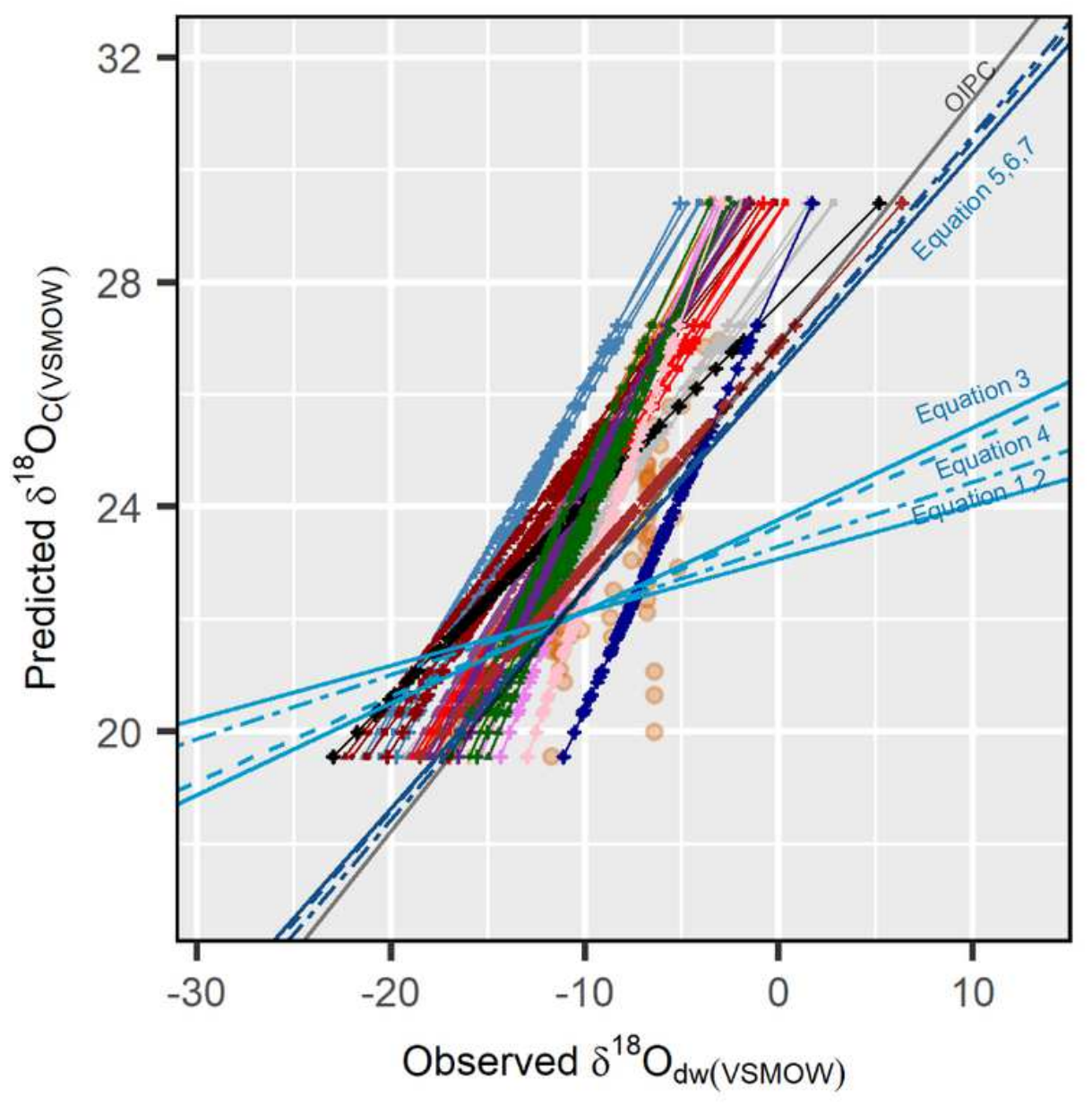

$\delta^{18} \mathrm{O}_{\mathrm{C}}$ to $\delta^{18} \mathrm{O}_{\mathrm{p}}$ equations

- Bryant et al. (1996)

- Chenery et al. (2012)

- lacumin et al. (1996)

+ Wright et al. (2010)

$\delta^{18} \mathrm{O}_{\mathrm{C} / \mathrm{P}}$ to $\delta^{18} \mathrm{O}_{\mathrm{dw}}$ equations

- Chenery et al. (2010)

- Daux et al. (2008) (Eq. 5)

- Daux et al. (2008) (Eq. 4)

- Daux et al. (2008) (Eq. 6)

Dotsika (2020)

- Ehleringer et al. (2010)

- Hermann et al. (2015)

- Keller et al. (2016)

$\rightarrow$ Levinson et al. (1987)

$\rightarrow$ Longinelli (1984)

- Luz et al. (1984)

- Pollard et al. (2011)

- Posey (2011)

- Warner et al. (2018)

Figure 11

$\delta 180 \mathrm{dw}$ values were calculated from all $\delta 180 c(V S M O W)$ values $(n=75)$ using an existing predictive model or a set of models. For those equations giving the relationship between Op to Odw, the values were first converted to Op from Oc using an equation that shows the relationship between carbonate and phosphate oxygen. Shapes denote carbonate to phosphate oxygen conversions. The OIPC line represents the relationship between $\delta 180 c(V M O S W)$ and $\delta 1800 I P C$ values. 

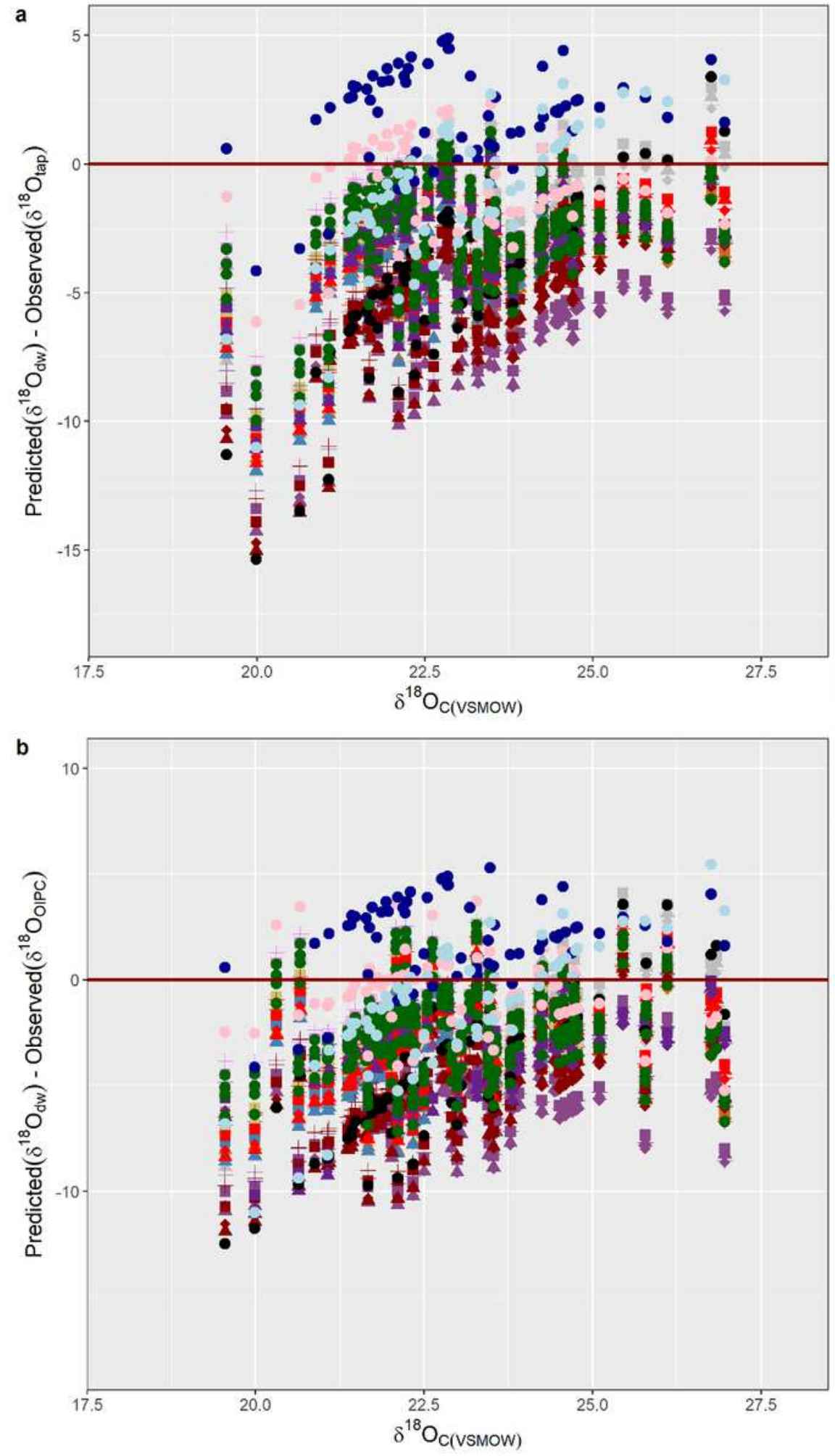

$\delta^{18} \mathrm{O}_{\mathrm{C}}$ to $\delta^{18} \mathrm{O}_{\mathrm{p}}$ equations

- Bryant et al. (1996)

- Chenery et al. (2012)

- lacumin et al. (1996)

+ Wright et al. (2010)

$\delta^{18} \mathrm{O}_{\mathrm{C} / \mathrm{P}}$ to $\delta^{18} \mathrm{O}_{\mathrm{dw}}$ equatior

- Chenery et al. (2010)

- Daux et al. (2008)(Eq.4)

- Daux et al. (2008)(Eq.5)

- Daux et al. (2008)(Eq.6)

Dotsika (2020)

- Ehleringer et al. (2010)

- Hermann et al. (2015)

Keller et al. (2016)

- Levinson et al. (1987)

- Longinelli (1984)

- Luz et al. (1984)

- Pollard et al. (2011)

- Posey (2011)

- Warner et al. (2018)

\section{Figure 12}

Differences between predicted and observed $\delta 180 \mathrm{dw}$ values for (a) tap water and (b) OIPC for all samples from the current study $(n=75)$. $\delta 180 \mathrm{dw}$ values were predicted from $8180 \mathrm{c}$ values with existing predictive models or a combination of models. $\delta 180 \mathrm{c}$ values were initially converted to $\delta 180 \mathrm{p}$ values before applying the equations that represent the relationship between $\delta 180 \mathrm{p}$ and $\delta 180 \mathrm{dw}$ values. 
Shapes denote carbonate to phosphate oxygen conversions, and colors represent the enamel to drinking water conversion equations.
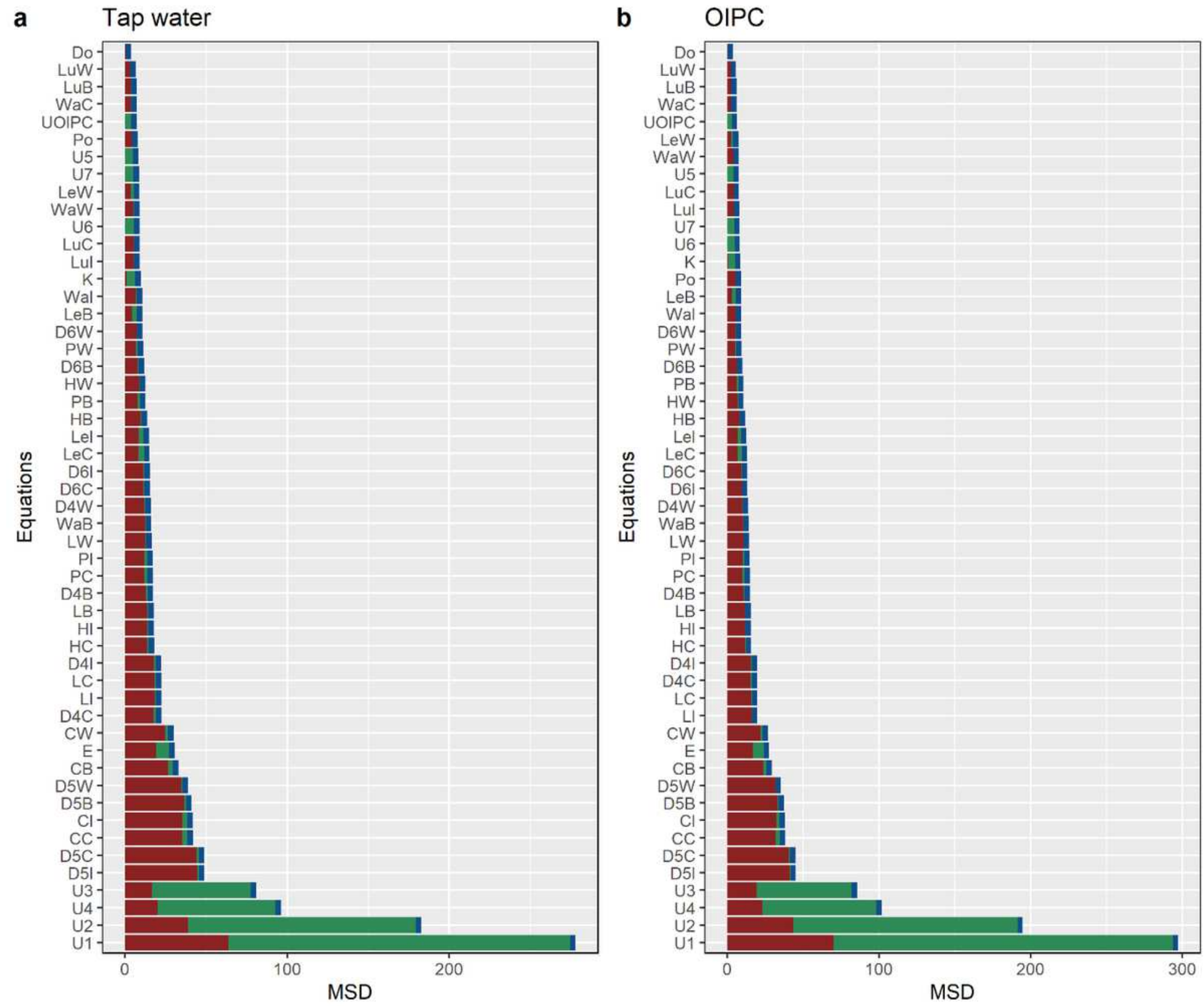

$\square$ LC $\square$ NU $\square$ SB

Figure 13

A direct comparison of the mean standard deviation (MSD) between predicted and observed $\delta 180 \mathrm{dw}$ values for (a) tap water and (b) OIPC. $\delta 180 \mathrm{dw}$ values were predicted from $\delta 180 \mathrm{c}$ values of all samples $(n=75)$ from the current study with existing predictive models or a combination of models. MSD components are lack of correlation (LC), non-unity slope (NU) and squared bias (SB). Low MSD indicates greater similarity between modelled and measured values.

\section{Supplementary Files}


This is a list of supplementary files associated with this preprint. Click to download.

- SupplementaryTableS1.xlsx

- SupplementaryTableS2.xlsx

- SupplementaryTableS3.xlsx

- SupplementaryTableS4.xlsx 